\title{
1 Delayed effects of climate on vital rates lead to demographic divergence in Amazonian forest fragments
}

$5{ }^{1}$ Department of Wildlife Ecology and Conservation, University of Florida, Gainesville,

6 Florida 32611-0430

$7 \quad 2$ Department of Ecology, Evolution and Environmental Biology, Columbia University 1200

8 Amsterdam Avenue, New York, New York 10027 USA

$9{ }^{3}$ Center for Latin American Studies, University of Florida, Gainesville, Florida 32611-5530

$10{ }^{4}$ Biological Dynamics of Forest Fragments Project, INPA-PDBFF, CP 478, Manaus,

11 Amazonas 69011-970 Brazil

12 Correspondence: Eric R. Scott<scottericr@gmail.com>

13 Keywords: Amazon; delayed effects; demography; distributed lag non-linear models;

14 drought; ENSO; habitat fragmentation; Heliconia acuminata; Heliconiaceae

15 Running title: Delayed effects of climate on vital rates 


\section{Abstract}

18 Deforestation often results in landscapes where remaining forest habitat is highly

19 fragmented, with remnants of different sizes embedded in an often highly contrasting

20 matrix. Local extinction of species from individual fragments is common, but the

21 demographic mechanisms underlying these extinctions are poorly understood. It is often

22 hypothesized that altered environmental conditions in fragments drive declines in

23 reproduction, recruitment, or survivorship. The Amazon basin, in addition to experiencing

24 continuing fragmentation, is experiencing climate change related increases in the

25 frequency and intensity of droughts and unusually wet periods. Whether plant populations

26 in tropical forest fragments are particularly susceptible to extremes in precipitation

27 remains unclear. Most studies of plants in fragments are relatively short (1-6 years), focus

28 on a single life-history stage, and often do not compare to populations in continuous forest.

29 Even fewer studies consider delayed effects of climate on demographic vital rates despite

30 the importance of delayed effects in studies that consider them. Using a decade of

31 demographic and climate data from an experimentally fragmented landscape in the Central

32 Amazon, we assess the effects of climate on populations of an understory herb (Heliconia

33 acuminata, Heliconiaceae). We used distributed lag non-linear models to understand the

34 delayed effects of climate (measured as standardized precipitation evapotranspiration

35 index, SPEI) on survival, growth, and flowering. We detected delayed effects of climate up

36 to 36 months. Extremes in SPEI in the previous year reduced survival, drought in the wet

37 season 8-11 months prior to the February census increased growth, and drought two dry

38 seasons prior increased flowering probability. Effects of extremes in precipitation on

39 survival and growth were more pronounced in forest fragments compared to continuous 
bioRxiv preprint doi: https://doi.org/10.1101/2021.06.28.450186; this version posted September 20, 2021. The copyright holder for this preprint (which was not certified by peer review) is the author/funder, who has granted bioRxiv a license to display the preprint in perpetuity. It is made available under aCC-BY-NC-ND 4.0 International license.

40 forest. The complex delayed effects of climate and habitat fragmentation in our study point

41 to the importance of long-term demography experiments in understanding the effects of

42 anthropogenic change on plant populations.

43 


\section{$44 \quad$ Introduction}

45 The expansion of agriculture and other human activities is a primary driver of

46 deforestation in the tropics (Alroy, 2017; Haddad et al., 2015). It also results in landscapes

47 where the remaining forest can be highly fragmented, with patches of different sizes

48 embedded in a matrix of often contrasting habitat (Bianchi \& Haig, 2013; Taubert et al.,

49 2018). This fragmentation is associated with myriad ecological changes, including the local

50 and regional extinction of plant species (da Silva \& Tabarelli, 2000; Laurance et al., 2006). It

51 is often hypothesized that the dramatically altered environmental conditions in tropical

52 forest fragments (Arroyo-Rodríguez et al., 2017; Didham \& Lawton, 1999; Ewers \& Banks-

53 Leite, 2013) drive declines in plant reproduction, recruitment, or survivorship (Bruna,

54 1999; Laurance et al., 1998; Zartman et al., 2015), although the demographic mechanisms

55 responsible for these extinctions are poorly understood (Bruna et al., 2009). Despite the

56 prevalence of this hypothesis (Betts et al., 2019; Didham \& Lawton, 1999; Laurance et al.,

57 2001), efforts to link population-level demographic responses with altered environmental

58 conditions in fragments remains scarce.

59 Studies in temperate systems have shown that the demography of species can also be

60 altered by climate change (Doak \& Morris, 2010; Selwood et al., 2015; Sletvold, 2005;

61 Williams et al., 2015). While the demographic consequences of climate change for tropical

62 species are expected to be similarly severe (Brodie et al., 2012; Scheffers et al., 2017),

63 surprisingly little is known about the responses of these species to climatic variability

64 (Paniw et al., 2021). Climate models predict increases in the areas of the Amazon effected

65 by severe drought and unusual wetness by the year 2100 (Duffy et al., 2015). Tropical

66 plants may be particularly sensitive to climate change-they typically have narrow ranges 
67 of climatic tolerance (Feeley et al., 2012), and recent results suggest increases in the

68 frequency and severity of extreme precipitation events (both drought and extreme wet)

69 reduce survival and reproduction (Esteban et al., 2021; Gaoue et al., 2019). This sensitivity

70 to climatic fluctuations, coupled with evidence that plant growth and survivorship are

71 lower in fragments (Bruna et al., 2002; Laurance et al., 1998; Zartman et al., 2015), has led

72 to speculation that plants in forest fragments will be especially susceptible to climate

73 change (Laurance et al., 2001; Opdam \& Wascher, 2004; Selwood et al., 2015).

74 The simultaneous pressures of climate change and habitat fragmentation may also result in

75 worse than additive impacts on demography (Holyoak \& Heath, 2016; Oliver et al., 2015).

76 For example, if fragments have a reduced capacity to buffer changes in microclimate

77 (Didham \& Lawton, 1999; Ewers \& Banks-Leite, 2013) or if fragment connectivity is climate

78 dependent (Honnay et al., 2002), populations experiencing habitat fragmentation will fare

79 worse under climate change.

80 Whether the demography of plant populations in tropical forest fragments is more

81 susceptible to climatic extremes remains unclear for three primary reasons. First, most

82 studies of plants in fragments have focused on a single life-history stage or process (Bruna

83 et al., 2009; Ehrlen et al., 2016), making it challenging to draw broader demographic

84 conclusions. Second, there is a growing literature on how tropical plants respond to

85 droughts (Esquivel-Muelbert et al., 2019; González-M et al., 2020; Uriarte et al., 2016), but

86 few studies have compared the responses of plants in continuous forest with those of

87 plants in forest fragments (Laurance et al., 2001). Finally, the multi-year data needed to

88 test population-level hypotheses about climate change and fragmentation are scant, 
89 especially for tropical systems (Crone et al., 2011; Salguero-Gómez et al., 2015). These data

90 are critical not simply because they allow for capturing variation in climatic conditions and

91 the resulting demographic responses (Morris \& Doak, 2002; Teller et al., 2016). They are

92 also essential because while some demographic effects of fragmentation or drought can be

93 detected immediately, others may take years to manifest (e.g., Gagnon et al., 2011). Indeed,

94 lagged responses of demographic vital rates to climate may be the rule rather than the

95 exception (Anderegg et al., 2015; Evers et al., 2021; Kannenberg et al., 2020; Schwalm et al.,

96 2017).

97 Herbaceous plants represent up to $25 \%$ of plant diversity in tropical forests (Gentry \&

98 Dodson, 1987), are critical food and habitat for myriad species (Snow, 1981), and are

99 economically and culturally vital (Nakazono et al., 2004; Ticktin, 2003). Nevertheless, the

100 impacts of global change phenomena on their demography remain conspicuously

101 understudied (Bruna et al., 2009). We used a decade of demographic and climatic data from

102 an experimentally fragmented landscape in the Central Amazon to assess the effects of

103 climate on populations of a tropical understory herb (Heliconia acuminata, Heliconiaceae).

104 This time series, which included the severe droughts of 1997 (McPhaden, 1999) and 2005

105 (Marengo et al., 2008; Zeng et al., 2008), allowed us to address the following questions: (1)

106 Does drought increase or decrease the growth, survival, and fertility of plant populations in

107 continuous forest? (2) Are there delayed effects of drought on demographic vital rates, and

108 if so what lag times are most critical? (3) Are the effects of drought on the vital rates of

109 populations in fragments similar in direction and magnitude to those in continuous forest? 


\section{Methods}

\section{Study site}

112 The Biological Dynamics of Forest Fragments Project (BDFFP) is located $\sim 70 \mathrm{~km}$ north of

113 Manaus, Brazil $\left(2^{\circ} 30^{\prime} \mathrm{S}, 60^{\circ} \mathrm{W}\right)$. In addition to large areas of continuous forest, the BDFFP

114 has forest fragment reserves isolated from 1980-1984 by felling the trees surrounding the

115 area chosen for isolation and, in most cases, burning the downed trees once they dried

116 (Bierregaard et al., 1992). In subsequent decades the vegetation regenerating around

117 fragments has been periodically cleared to ensure fragment isolation (Bierregaard et al., 118 2001).

119 The BDFFP reserves are located in nonflooded (i.e., terra firme) tropical lowland forest

120 with a 30-37m tall canopy (Rankin-de-Mérona et al., 1992) and an understory dominated

121 by stemless palms (Scariot, 1999). The soils in the reserves are nutrient-poor xanthic

122 ferrosols; their water retention capacity is poor despite having a high clay content. Mean

123 annual temperature in the region is $26^{\circ} \mathrm{C}$ (range $=19-39^{\circ} \mathrm{C}$ ), and annual rainfall ranges

124 from $1900-2300 \mathrm{~mm}$. There is a pronounced dry season from June to October (Figure S1).

125 Focal species

126 Heliconia acuminata (LC Rich.) (Heliconiaceae) is a perennial monocot distributed

127 throughout Central Amazonia (Kress, 1990) and is the most abundant understory herb at

128 the BDFFP (Ribeiro et al., 2010). While many Heliconia species grow in large patches in

129 treefall gaps and other disturbed areas, others, such as H. acuminata, are found at lower

130 densities in the darker and cooler forest understory (Rundel et al., 2020). These species

131 produce fewer inflorescences and are pollinated by traplining rather than territorial 
132 hummingbirds (Bruna et al., 2004; Stouffer \& Bierregaard, 1996). In our sites H. acuminata

133 is pollinated by Phaeothornis superciliosus and P. bourcieri (Bruna et al., 2004). Plants begin

134 flowering at the start of the rainy season; reproductive plants have $\bar{x}=1.1$ flowering

135 shoots (range = 1-7), each of which has an inflorescence with 20-25 flowers (Bruna \&

136 Kress, 2002). Fruits mature April-May, have 1-3 seeds per fruit ( $\bar{x}=2)$, and are eaten by a

137 thrush and several species of manakin (Uriarte et al., 2011). Dispersed seeds germinate

138 approximately 6 months after dispersal at the onset of the subsequent rainy season, with

139 rates of germination and seedling establishment higher in continuous forest than forest

140 fragments (Bruna, 1999; Bruna \& Kress, 2002).

\section{Demographic data collection}

142 This study uses data collected in four 1-ha fragment reserves and six continuous forest

143 sites. In 1997-1998 we established a $5000 \mathrm{~m}^{2}$ plots $(50 \times 100 \mathrm{~m})$ in each of these sites in

144 which we marked and measured all Heliconia acuminata; plots in 1-ha fragments were on

145 one randomly selected half of the fragment, while plots in continuous forest were located

$146500-4000 \mathrm{~m}$ from the borders of secondary and mature forest. The distance between plots

147 ranged from $500 \mathrm{~m}-41 \mathrm{~km}$. Our dataset comprised 4,886 plants in continuous forest and

1481,375 plants in forest fragments. Plots in CF had on average more than twice as many

149 plants than plots in 1-ha fragments $(\mathrm{CF}$ median $=788$, range $=[201,1549]$; 1 -ha median $=$

150339 , range $=[297,400])$.

151 Each plot was subdivided into 50 quadrats $(10 \times 10 \mathrm{~m})$ to simplify annual surveys, during

152 which we recorded the number of vegetative shoots each plant had, the height of each plant

153 (i.e. distance from the ground to the tallest leaf tip), and whether each plant was flowering 
154 (height and shoot number are correlated with leaf area, the probability of flowering, and

155 rates of survivorship (Bruna, 2002; Bruna \& Kress, 2002). In this study, we used the

156 product of shoot number and plant height as our measure of plant size. Preliminary

157 analysis showed that the product of shoot number and height was a better predictor of

158 total leaf area (which in turn is assumed to be a strong predictor of aboveground biomass)

159 than either shoot number or height alone (Table S2). After the initial census year, between

$16080 \%$ and $97 \%$ of marked plants were found at each survey. Of plants that had missing

161 values for some years, but were found again in a subsequent year, 95\% had 2 or fewer

162 years of missing values. Therefore, plants that were not found for three consecutive

163 surveys, and no subsequent survey, were considered to have died in the transition year

164 after their last observation. We also surveyed plots regularly during the rainy season to

165 identify any that flowered after the survey. For additional details on the location of plots,

166 survey methods, and H. acuminata population structure see Bruna \& Kress (2002).

\section{Climate data}

168 Data on precipitation and potential evapotranspiration in our sites were obtained from a

169 published gridded dataset $\left(0.25^{\circ} \times 0.25^{\circ}\right.$ resolution $)$ built using data from 3,625 ground-

170 based weather stations across Brazil (Xavier et al., 2016). We used these data to calculate

171 the standardized precipitation evapotranspiration index (SPEI) (Vicente-Serrano et al.,

172 2010). SPEI is a proxy for meteorological drought that integrates precipitation and

173 evapotranspiration anomalies over a specified time scale. Positive SPEI values for a given

174 month indicate conditions wetter than the historical average for that month, while negative

175 values of SPEI indicate droughts with intensity categorized as mild (0 to -1), moderate (-1

176 to -1.5$)$, severe $(-1.5$ to -2$)$, or extreme $(<-2)$ (McKee et al., 1993). SPEI can be calculated to 
177 represent different temporal scales of drought; we used 3-month SPEI because-given its

178 shallow roots and rhizome-H. acuminata relies primarily on soil moisture rather than

179 deeper water sources that can persist for longer timescales (McKee et al., 1993; Vicente-

180 Serrano et al., 2010). Note that 3-month SPEI is still monthly data-each month's SPEI

181 value simply takes into account precipitation and evapotranspiration of the previous three

182 months. SPEI calculations were made using the SPEI package in R (Beguería \& Vicente-

183 Serrano, 2017). The timing of drought events based on these SPEI calculations is consistent

184 with that resulting from SPEI calculated with other data sources, though the magnitude of

185 drought sometimes differed (Figure S2; Table S1 ).

\section{Statistical Modeling of Vital Rates}

187 To assess the effects of drought history on plant vital rates we used Distributed Lag Non-

188 linear Models (DLNMs, Gasparrini et al., 2017). DLNMs capture how potentially delayed

189 effects of predictor variables (e.g. SPEI) affect an outcome (e.g. growth) well beyond the

190 event period. DLNMs avoid the problems of including all possible climate windows in a

191 single model-namely collinearity of predictors and the arbitrary choice of window length.

192 They do so by fitting a bi-dimensional predictor-lag-response association spline, referred to

193 as a crossbasis function. This models a non-linear relationship between predictor and

194 response (e.g. between SPEI and vital rates) and allows the shape of that relationship to

195 vary smoothly over lag time. The shape of the function can be penalized so that it is only as

196 complex as the data supports, thus reducing effective degrees of freedom. We used a

197 crossbasis function of SPEI and lag time with possible lags from 0-36 months. We chose 36

198 months as a maximum lag because prior transplant experiments with $H$. acuminata showed

199 they typically recover from transplant shock in less than 36 months (Bruna et al., 2002) so 
200 this is a reasonable upper bound for lagged effects of drought. The general form of the vital 201 rate $(y)$ models was as follows:

$$
\begin{aligned}
& g\left[\mathrm{E}\left(y_{i j}\right)\right]=\alpha_{j}+s_{1}\left(z_{i}\right)+s_{2}\left(d_{i, t}, \ldots, d_{i, t-36}\right)+\beta x_{i} \\
& \alpha_{j} \sim N\left(\mu_{\alpha_{j}}, \sigma^{2}\right), \text { for plot j }
\end{aligned}
$$

203 where $y_{i j}$ is the $i$ th plant observation in the $j$ th plot $s_{1}\left(z_{i}\right)$ is a smooth function of plant size

204 (natural log of height $\times$ shoot number), fit using a penalized cubic regression spline, $s_{2}(\cdot)$ is

205 the crossbasis function in which $d_{i, t}$ is the SPEI value during the census month of an

206 observation (February) and $d_{i, t-l}$ is the SPEI $l$ months prior (see Gasparrini et al. 2017 for

207 details). To determine if plot characteristics influenced average vital rates we included a

208 random effect of plot ID on the intercept; this was represented by $a_{j}$ in eq. 1 . We modeled a

209 potential cost of reproduction by including flowering in the previous year as covariate, $x_{i}$,

210 in eq. 1. Individual-level random effects were not included due to computational limitations

211 in fitting random intercepts for all of the nearly 5,000 plants in continuous forest plots.

212 Fitting models with a data subset with and without individual-level random effects showed

213 that excluding individual-level random effects reduced model $\mathrm{R}^{2}$, but did not affect the

214 shape or statistical significance of the smooths.

215 The crossbasis function, $s_{2}(\cdot)$ can also be written:

$$
s_{2}\left(d_{i, t}, \ldots, d_{i, t-24}\right)=\sum_{l=l_{0}}^{L} f \cdot w\left(d_{i, t-l}, l\right)
$$

217 where the crossbasis function, $f \cdot w(d, l)$, is composed of two marginal basis functions: the

218 standard predictor-response function $f(d)$, and the additional lag-response function $w(l)$. 
219 These marginal functions are combined as a tensor product smooth such that the shape of

220 one marginal function varies smoothly along the other dimension (see chapter 5 of Wood

221 (2017) and Gasparrini et al. (2017) for more detail). Penalized cubic regression splines

222 were used for both marginal bases of the crossbasis function. We increased $k$, the

223 maximum basis dimension, as necessary to be sure it was adequate (Appendix A). Because

224 of penalization, the maximum basis dimension is generally not important as long it is large

225 enough to allow the smooth to represent the 'true' relationship (Wood, 2017). Estimated

226 degrees of freedom (edf) represent the 'true' complexity of the smooth after penalization

227 with edf $=1$ being equivalent to a straight line and larger numbers representing more

228 complex curves.

229 The crossbasis function was fit to the data in the context of a generalized additive model

230 (GAM) with restricted maximum likelihood using the mgcv R package (Wood, 2017). The

231 crossbasis smooth was coded as:

232 s(spei_history, $L$, bs = "cb", xt = $\operatorname{list}(b s=" c r ")$ )

233 Where spei_history is a $n \times m$ matrix with each row $(n)$ containing the climate history of

234 a single plant in a year and $m=36$ columns representing the past weather conditions

235 starting at the month of the census and going backwards in time 36 months. L is an $n \times m$

236 matrix with columns describing the lag structure, i.e. the integers 0 through 36 . The spline

237 basis, "cb" is provided by the dlnm package (Gasparrini, 2011), and we specified the

238 marginal bases as cubic regression splines with the xt argument. For the full code used to

239 fit the models, see the Data Availability Statement. 
240 We determined the effects of SPEI on plant growth using plant size in year $\mathrm{t}+1$ as a

241 response variable. This was modeled with a scaled t family error distribution because

242 residuals were leptokurtic when a Gaussian family was used. Because number of

243 inflorescences was highly zero-inflated, we converted this to a binary response to model

244 reproduction (i.e., 1 for $\geq 1$ inflorescence, 0 for no inflorescences). We modeled both

245 reproduction and survival (i.e., from year $t$ to year $t+1$ ) using a binomial family error

246 distribution with a logit link function.

247 In the process of fitting the models, the penalty on the crossbasis smooth (and other

248 smoothed terms) is optimized such that more linear shapes are favored unless the data

249 supports non-linearity (Wood, 2017). We applied an additional penalty to shrink linear

250 portions toward zero with the select=TRUE option to the gam( ) function, and inferred

251 statistical significance of model terms with p-values from the summary.gam( ) function as

252 recommended in Marra \& Wood (2011).

253 The dlnm package does not currently allow the modeling of interaction terms, which means

254 we could not asses the interaction of habitat type and lagged effects. We therefore fit

255 separate models for plants in fragments and in continuous forest to allow the shape of the

256 crossbasis function to differ between habitats. Significant main effects of habitat type were

257 assessed by looking for overlap in the 84\% confidence intervals of model intercepts; the

258 84\% CIs of two samples drawn from the same population overlap about 95\% of the time

259 (Payton et al., 2003).

260 To visualize results, we plotted partial effects plots for the one-dimensional smooth

261 function of log size in the previous year and the two-dimensional smooth function of lagged 
262 SPEI (the crossbasis function) for each model. To make these plots more interpretable, we

263 added the model intercept and (when applicable) back-transformed the y-axis to be on the

264 scale of the response (e.g. a probability for survival and flowering).

265 All analyses were conducted in R version 4.0.2 (2020-06-22) (R Core Team, 2020) using

266 the targets package for workflow management (Landau, 2021). Figures were created with

267 the aid of the gratia, ggplot2, and patchwork packages (Pedersen, 2020; Simpson, 2021;

268 Wickham, 2016).

269 Results

270 The meteorological droughts in our focal region indicated by SPEI are generally consistent

271 with those reported in the literature (Table S1). For example, the drought associated with

272 the 1997 El Niño Southern Oscillation (ENSO) event was one of the most severe on record

273 for the Amazon (Williamson et al., 2000); correspondingly, 1997 has the lowest SPEI values

274 in our timeseries (Figure 1d). The 2005 dry season (June-October) was also reported as an

275 exceptionally dry year, although this drought mostly affected the southwestern Amazon

276 (Marengo et al., 2008; Zeng et al., 2008). Our SPEI data show the 2005 dry season to be a

277 moderate drought $(-1>$ SPEI $>-1.5)$.

278 Survival, size, and flowering in continuous forest vs. fragments

279 Survival: Across all plots, the proportion of plants surviving was lowest in the 2003-2004

280 transition year (93\% survival in both continuous forest and forest fragments). This

281 coincided with droughts in both the 2003 and 2004 rainy seasons (Figure 1 b,d) and was

282 preceded by a drop in average plant size in the 2002-2003 transition year (i.e. negative

283 growth in Figure 1a). There was no significant difference in survival between continuous 
284 forest and 1 ha fragments (Table 1). Although differences in survival probability are small

285 and not statistically significant, these slight differences can be seen to compound over time

286 in the survivorship of plants labeled in the first year of the surveys (Figure 2). Survival in

287 both habitats was significantly affected by size in the previous year (Table 2) with larger

288 plants having much greater survival probabilities (Figure 3b). The survival probability of

289 large plants approached 1 in both habitat types, but the smallest plants had higher survival

290 in 1 ha fragments (although 95\% confidence intervals overlap at all sizes).

291 Size: Plants in continuous forest had an average of 2.9 shoots $( \pm 1.8$ SD) and were on

292 average $39.8 \mathrm{~cm}$ tall $( \pm 26.2$ SD). Plants in 1-ha fragments had on average $14 \%$ fewer

293 shoots $(2.5 \pm 1.4 \mathrm{SD})$ and were $10.5 \%$ shorter $(35.6 \mathrm{~cm} \pm 23.8 \mathrm{SD})$. Because our proxy for

294 plant size was the product of these two metrics, plants in continuous forest were on

295 average 32\% larger than those in forest fragments $(144 \pm 176$ SD vs. $109 \pm 139$ SD,

296 respectively), with fragments having proportionately fewer large plants (Figure 3d). Plants

297 were significantly larger in continuous forest on average (Table 1), and the disparity in

298 plant size - which was most pronounced in the initial years of our surveys-diminished

299 over time.

300 Mean plant size dropped dramatically in 2003 in both habitat types (negative fold-change

301 in Figure 1a), corresponding with a severe drought during the February census $(\mathrm{SPEI}=-$

302 1.39) (Figure 1d). As with survival, size in year t was a significant predictor of size in year

$303 t+1$ (Table 2). Although plants were significantly larger in continuous forest compared to

304 fragments (Table 1 ), the effect of size in year $t$ on size in year $t+1$ is nearly identical in the

305 two habitats (Figure 3a). 
306 Flowering: The overall proportion of plants that flowered was very low, but the proportion

307 of plants flowering was $31 \%$ higher in continuous forest than 1 -ha fragments $(4.6 \%$

308 vs. 3.5\%, respectively). The intercepts for the continuous forest and 1 ha fragment models

309 were significantly different, indicating a main effect of habitat on flowering probability

310 (Table 1). The observed disparity in proportion of flowering plants was largely due to the

311 fact that flowering is also significantly size-dependent (Table 2), with the probability of

312 flowering increasing dramatically once plants reached the threshold size of about 148 (i.e.,

$313 \log ($ size $)>5$ in Figure 3c). Despite the flowering probability of the largest plants being

314 greater in fragments than continuous forest, populations in fragments had proportionately

315 fewer plants above the reproductive size threshold (Figure 3d). The most striking

316 differences between habitat types coincided with relatively extreme weather conditions. In

317 2003, during the onset of a severe drought, the proportion of potentially reproductive

318 plants (i.e. plants above the size-threshold for reproduction) that actually flowered was

$31928 \%$ in continuous forest vs. $17 \%$ in 1 -ha fragments. In 2006 , following a wet spring and

320 winter (SPEI > 1), the trend was reversed: only 14\% of these plants flowered in continuous

321 forest vs. 26\% in 1-ha fragments (Figure 1c). Note that plots in 1-ha fragments generally

322 have fewer and smaller plants than those in continuous forest, so total numbers of

323 flowering plants was always lower in fragments.

\section{Delayed effects of drought on demographic vital rates}

325 Drought history had a significant effect on the survival, growth, and flowering of plants in

326 both habitats (Table 2). Comparing the respective crossbasis surfaces, however, reveals

327 that the specific climatic drivers, their timing, and their impact on individual vital rates all

328 differed among habitats. 
329 Survival: For 1-ha fragments, there was a significant effect on survival of SPEI in the

330 preceding 0-16 months. The highest survival was near SPEI of 0, with mortality increasing

331 as conditions became either drier or wetter (i.e., as SPEI values became increasingly

332 negative or positive, respectively; Figure 4b). Additionally, a positive, lagged effect of high

333 SPEI at 32-36 months lag reached statistical significance. There was less of a delayed effect

334 of SPEI on survival in continuous forest with only the preceding 0-4 months and 32-36

335 months reaching statistical significance (Figure 4a). The short-term effects of SPEI on

336 survival in continuous forest were also unidirectional-the probability of survival was

337 highest in wet conditions and declined, albeit only slightly, with increasingly negative

338 values of SPEI (i.e., as droughts became more severe; Figure 4a). Plants in both habitat

339 types showed an increase in survival probability with very high SPEI values (i.e., extremely

340 high precipitation) at a lag time of 32-36 months. It should be noted, however, that only the

341 first transition year of census data (1998-1999) met these conditions. We compared the

342 effects of SPEI history in continuous forest and fragments by subtracting the fitted values in

343 Figure $4 \mathrm{~b}$ from Figure $4 \mathrm{a}$ to produce Figure 4c. This shows that in average conditions (SPEI

$344=0$ ), there is little difference in survival probability between continuous forest and forest

345 fragments (Figure 4c). However, under extreme conditions, survival probability is up to

3460.042 higher in continuous forest than fragments.

347 Size: The effects of drought history on trends in plant size were generally similar for

348 continuous forest and fragments. Under all conditions, plant size is greater in continuous

349 forest (Figure 5c). Decreasing SPEI at lags of 8-11 months (i.e., the end of the preceding

350 year's wet season) led to increased growth in both habitats. In continuous forest, but not 1-

351 ha fragments, SPEI at lags of 22-25 months had a significant effect on plant size in the 
352 opposite direction, with wet conditions at that lag time resulting in larger predicted sizes.

353 At longer lags of 26-36 months positive effects of drought on plant size are predicted for

354 both continuous forest and 1-ha fragments by our models, although the area of SPEI-lag

355 space that reaches statistical significance is larger for continuous forest.

356 Flowering: Overall, the probability of flowering was significantly higher in continuous

357 forest than in 1-ha fragments (Figure 6, Table 1). Recent and past SPEI had less of an effect

358 on flowering probability in 1-ha fragments as indicated by the narrower range of the

359 evaluated smooth (Figure 6b). This led to some important inter-habitat differences in plant

360 responses to prior droughts. In continuous forests, recent drought (i.e., at lag $=0-2$ with

361 SPEI <-1) and droughts two dry seasons prior (lags 15-20) increased the probability of

362 flowering. The shape of the crossbasis smooth for 1-ha fragments suggested that moderate

363 drought $(-1.5<\mathrm{SPEI}<-1)$ in the previous $0-18$ months and at lags of $28-36$ months

364 significantly increased flowering probability slightly (the highest probability estimated is

365 0.004; Figure 6b). The effects of drought on flowering probability appeared stronger in

366 continuous forest compared to 1-ha fragments (Figure 6c). We found no evidence for a cost

367 of reproduction: in both forest and fragments, plants that had flowered in the previous year

368 were significantly more likely to be larger and flower again. Finally, with the exception of

369 the model for survival in 1-ha fragments, the random effect of plot was significant,

370 indicating that vital rates varied among plots (Table 2).

\section{Discussion}

372 Understanding how landscape structure and abiotic conditions act to influence population

373 dynamics is central to many conceptual frameworks for studying and conserving 
374 fragmented landscapes (Didham et al., 2012; Driscoll et al., 2013). Our results support the

375 emerging consensus that the effects of climatic extremes on demographic vital rates can be

376 delayed for months or even years (Evers et al., 2021; Teller et al., 2016; Tenhumberg et al.,

377 2018). We also found different magnitudes, directions, and lag times of climate effects in

378 fragments and continuous forests. This suggests that the hypothesized synergies between

379 climate and fragmentation on population dynamics (Laurance \& Williamson, 2001; Opdam

380 \& Wascher, 2004; Selwood et al., 2015) may be important in this system in a way far more

381 complex than previously thought.

\section{Temporal variation in demographic responses to forest fragmentation}

383 Many studies investigating the biological consequences of habitat fragmentation on plant

384 growth, survival, and reproduction comprise short-term $(\leq 3$ year $)$ experiments and

385 observations. Our results underscore the difficulty in extrapolating long-term trends from

386 such short-term studies, particularly when studying long-lived organisms or when the

387 responses of interest can vary with size or age. For instance, one would have reached a very

388 different conclusion regarding the effect of fragmentation on annual survival if the study

389 windows were 1999-2002 (i.e., higher survival in continuous forest), 2002-2005 (i.e.,

390 higher survival in fragments), or 2004-2007 (i.e, no clear effect of fragmentation) (Figure

391 1b). It is only when evaluating over longer time windows that it becomes apparent

392 mortality is elevated in fragments relative to continuous forest (Figure 2), and that the

393 observed interannual variation is largely driven by dynamic patterns of recruitment

394 (Bruna, 2002) coupled with low mortality for plants beyond the smallest size classes

395 (Bruna, 2003). 
396 Similarly, conclusions regarding the effects of fragmentation on flowering-which is also

397 both rare and size-dependent (Brooks et al., 2019)—would also differ based on the year in

398 which they were investigated. This could lead to erroneous extrapolations regarding the

399 effects of fragmentation on reproductive mutualists or population genetic structure (Côrtes

400 et al., 2013; Uriarte et al., 2010; Uriarte et al., 2011). Conclusions based on short-term

401 observations of temporally variable vital rates could lead to conservation and management

402 practices that are ineffective or even counterproductive, especially when when failing to

403 consider how the consequences of this variation might be modulated by organismal life

404 history (Morris et al., 2008).

405 It is important to emphasize, however, that the range of the estimated response to SPEI for

406 survival and growth was greater in fragments compared with continuous forest (Figures 4,

407 5). This suggests that extremes in SPEI may be more detrimental in forest fragments

408 compared with continuous forest. While intact forest and its canopy buffer populations

409 from climatic extremes, populations in fragments-especially near edges with high

410 contrast matrix - likely lack this protection (Didham \& Lawton, 1999; Ewers \& Banks-Leite,

411 2013). We suggest it is these climate extremes, rather than trends in average temperature,

412 precipitation, or SPEI (Laurance et al., 2014), that that are the causal mechanism

413 underlying the observed reduced plant survival and size in forest fragments.

\section{Delayed effects of climate on demographic vital rates}

415 Climate anomalies are known to have immediate effects on the growth, survival, or

416 reproduction of plants (Esteban et al., 2021; Wright \& Calderon, 2006), including Heliconia

417 (Stiles, 1975; Westerband et al., 2017) and other tropical herbs (Wright, 1992). These 
418 effects can be complex or even contradictory-mild droughts can increase the growth rates

419 of tropical trees and seedling survival, perhaps due to reductions in cloud cover and

420 concomitant increases in solar radiation (Alfaro-Sánchez et al., 2017; Condit et al., 2004;

421 Huete et al., 2006; Jones et al., 2014; Uriarte et al., 2018), but in severe drought years

422 growth can be extremely low and mortality can be sharply elevated (Connell \& Green,

423 2000; Edwards \& Krockenberger, 2006; Engelbrecht et al., 2002). There is also evidence

424 that the effects can persist for multiple years (Phillips et al., 2010), such as a boom in

425 drought-year fruit production followed by severe post-drought "famine" (Pau et al., 2013;

426 Wright et al., 1999).

427 Despite these insights, models of plant population dynamics rarely include the effects of

428 environmental drivers [but see Williams et al. (2015); Tenhumberg et al. (2018); Molowny-

429 Horas et al. (2017)). This has largely been due to the challenge (both ecologically and

430 statistically) of detecting any demographic responses to climatic extremes that are delayed

431 for multiple growing seasons. To address this, researchers have begun to use a number of

432 statistical methods that test for time lags in demographic responses without a priori

433 assumptions about the influence of any particular climate window (Evers et al., 2021; Ogle

434 et al., 2015; Teller et al., 2016; Tenhumberg et al., 2018). Our results are consistent with

435 this emerging literature - that the effects of precipitation extremes on the demography of

436 Heliconia acuminata could be delayed for up to 3 growing seasons. Additionally, our

437 method allowed us to capture significant non-linear responses to SPEI at different lag

438 times, which appear to differ in shape between habitats. 
439 While it appears that delayed effects of climate on demographic vital rates may be

440 ubiquitous (Evers et al., 2021), the extent to which they vary spatially or with habitat

441 remains an open question. Our results suggest that they may, with habitat-specific

442 differences in how environmental conditions influenced future vital rates. For example,

443 extreme values of SPEI — both positive (unusually high precipitation) and negative

444 (drought conditions) - led to declines in the probability of individual survival in forest

445 fragments while extreme wet conditions significantly increased survival in continuous

446 forest. Similarly, the marginal effects of SPEI on plant size were greater in fragments,

447 suggesting a more pronounced effect of extreme climates in fragments. In contrast,

448 variation in SPEI corresponded to a greater range of flowering probabilities in continuous

449 forest than fragments. These results should be interpreted with some caution, however, as

450 the relatively low number of plants in fragments that are above the threshold-size for

451 flowering could limit the power to detect delayed effects.

452 Interestingly, we found significant detrimental effects of unusually wet conditions at some

453 lag times for all vital rates except survival in continuous forest and flowering probability in

454 1-ha fragments. While most studies investigating how precipitation extremes influence

455 tropical plants have focused on droughts (Lewis et al., 2011; Phillips et al., 2009;

456 Williamson et al., 2000), more recent work has shown that unusually wet conditions can

457 also be detrimental (Esteban et al., 2021). For instance, the increased cloud cover

458 associated with elevated precipitation could lead to reduced photosynthetic activity and

459 growth; plants in the resulting saturated soils could also have lower growth and elevated

460 mortality (Parent et al., 2008). The wind storms accompanying extreme precipitation

461 events (Espírito-Santo et al., 2010; Negrón-Juárez et al., 2018) could increase the likelihood 
462 of tree-, branch-, and litter-fall, all of which are sources of mortality for understory plants

463 (Scariot, 2000; Ssali et al., 2019). Finally, cool temperatures associated with unusually wet

464 conditions may decrease flowering (Pau et al., 2013).

465 There are several, non-mutually-exclusive explanations for delayed effects of SPEI on

466 demography. The first is that the physiological processes underlying vital rates might be

467 initiated long before they are demographically apparent (Evers et al., 2021), and hence be

468 shaped by climatic events at any point in that physiological window. For example, the

469 flowering shoots of Heliconia chartacea begin to develop 6-10 months prior to the

470 appearance of inflorescences (Criley \& Lekawatana, 1994). Adverse conditions during the 6

471 months following initiation, rather than the months when inflorescences are starting to

472 expand, leads to the aborted production of flowering shoots. Our results showed delayed

473 increases in flowering probability after drought. Drought conditions could be favorable for

474 H. accuminata flowering due to increased temperatures or decreased cloudiness associated

475 with droughts (Pau et al., 2013), and the effects could be delayed due to the development

476 time of inflorescences.

477 Demographic responses will also be delayed if abiotic stress causes plants to invest in

478 belowground rhizomes (sensu Pumisutapon et al., 2012). The carbohydrates stored in

479 rhizomes allow Heliconia to regenerate aboveground biomass following damage (Rundel et

480 al., 1998) and protect the buds that give rise to new shoots from stressful conditions

481 (Klimešová et al., 2018). This may be why drought led to delayed increases in growth-by

482 shedding shoots and leaves and investing in rhizomes, plants could be generating

483 proportionately more buds with which to regenerate when conditions improve. This is 
484 consistent with the results of prior experiments in which $H$. acuminata plants transplanted

485 into hotter, drier fragments lost and then recovered far more leaf area than control plants

486 (Bruna et al., 2002).

487 Third, it may be that the delayed demographic effects we observed are indirectly mediated

488 by the effect of SPEI on other species rather than the direct effects on individual physiology

489 (Evers et al., 2021). For example, topical trees may not die until three or more years after a

490 drought (Criley \& Lekawatana, 1994). When they finally do, the resulting leaf drop (Janssen

491 et al., 2021) and treefalls allow for light penetration to the forest understory (Canham et al.,

492 1990; Leitold et al., 2018), triggering a boom in the growth and flowering of understory

493 plants (Bruna \& Oli, 2005). Similar delayed changes in the local environment could also

494 influence the foraging behavior of a plant's pollinators (Bruna et al., 2004; Stouffer \&

495 Bierregaard, 1996), seed dispersers (Uriarte et al., 2011), or herbivores (Scott et al., 2021).

496 While more work is needed to explain why the (delayed) effects of SPEI on H. acuminata

497 survival and growth are greater in fragments than forest interiors, one hypothesis,

498 motivated by recent intriguing results from other systems (Sapsford et al., 2017), is that the

499 greater litterfall on edges (Vasconcelos \& Luizão, 2004) may be altering the abundance of

500 pathogens or mycorrhizae.

501 Finally it is important to clarify the distinction between "physiological delays" and

502 “observational delays." For example, a Fall drought could reduce cold tolerance and

503 therefore overwinter survival. Alternatively the drought could kill plants immediately. If

504 mortality is recorded in Spring, then mortality would appear as a delayed effect of the

505 drought in both hypothetical cases, but only the first case is a truly delayed physiological 
506 response to drought. The apparent delayed response in the second case is due to the timing

507 of the response in relation to the census date. In our analysis, this potential explanation of

508 "observational delays" applies only to plant size and survival, as the flowering season

509 coincided with the yearly census. It also only applies to lags of up to 12 months since

510 mortality, size, and flowering are recorded yearly. This possibility is not unique to our

511 study, rather it is a consequence of conducting demographic censuses on an annual scale

512 while the climate is quantified monthly or seasonally. For some demographic models and

513 follow-up experiments, knowing the precise timing of mortality might be critical; for others

514 less so. To disentangle possible mechanisms for observed delayed effects, it may be

515 necessary to conduct demographic surveys at the same temporal scale at which climate is

516 aggregated.

\section{Conclusions \& Future Directions}

518 Over 24 million ha of the Brazilian Amazon have been cleared in the last two decades (Silva

519 Junior et al., 2021), resulting in their extensive fragmentation (Broadbent et al., 2008).

520 Climate models predict a future of extremes for these forests-increases in the frequency

521 and geographic extent of droughts, but also increases in the frequency and area affected by

522 periods of unusual wetness (Duffy et al., 2015). Our results support the hypothesis that

523 populations in Amazonian forest fragments could be more susceptible to the effects of

524 changing climate than those in continuous forest (Laurance et al., 2014). However, they

525 also indicate that the demographic responses to climate change of populations in

526 fragmented landscapes may be far more complex than previously appreciated. Multi-

527 factorial, multi-season experiments (sensu Aguirre et al., 2021; Bruna \& Ribeiro, 2005;

528 Markewitz et al., 2010; Westerband et al., 2017), ideally manipulating multiple 
529 combinations of climatic variables (Mundim \& Bruna, 2016), are needed to determine how

530 and why habitat-specific differences in environmental conditions interact to delay the

531 demographic responses of plants to climatic variability. Also needed are statistical tools

532 that can test for synergistic effects of fragmentation and climate in vital rates, as those

533 currently available do not allow for including interaction terms. This also limits the ability

534 to include size by climate interactions in a DLNM; although plant responses to both

535 fragmentation and climatic extremes can be size-specific (Bruna \& Oli, 2005; Schwartz et

536 al., 2019). The ability to identify size-specific lagged responses may be especially

537 complicated given size is rarely measured at the same time scale (e.g. monthly) as climate

538 drivers.

539 Recent research, including our own presented here, shows that lagged effects of climate

540 drivers on demography may be the norm (Evers et al., 2021). As such, we suggest that all

541 demographers investigate the possibility of lagged environmental effects, ideally using

542 methods that do not require an a priori choice of lag times such as DLNMs, automated

543 algorithms for choosing critical weather windows (van de Pol et al., 2016), or Bayesian

544 methods that incorporate "ecological memory" (Ogle et al., 2015).

545 Finally, any analytical approach for assessing lagged effects on demography requires long-

546 term data and/or data collected from many sites with independent weather (but similar

547 climate and site conditions) (Evers et al., 2021; Tenhumberg et al., 2018). Teller et al.

548 (2016) used a simulation study to show that detecting lagged effects required 20-25 years

549 of data, although this depended on effect size and the range of climate extremes in the data.

550 Work in progress from Compagnoni et al. (2021) showed that spatial replication may 
551 alleviate this requirement, and in fact in our study we were able to detect significant lagged

552 effects with only 10 years of data and multiple plots experiencing slightly different

553 weather. Unfortunately, long-term data monitoring the entire life-cycle of tropical taxa are

554 rare, and those doing so in fragmented landscapes are virtually nonexistent (Bruna \&

555 Ribeiro, 2005). Without investing in collecting such data, generalizations regarding the

556 demographic consequences of climate change in these species rich and increasingly

557 fragmented habitats will continue to prove elusive. More generally, however, researchers

558 need to consider how delayed responses to climate could influence the interpretation of

559 data in studies where the organisms lifespan exceeds the study's duration.

560 Acknowledgments

561 We thank Collin Edwards, Andrew Mercadante, Ellie McDaniel and 3 anonymous reviewers

562 for helpful discussions and comments on the manuscript. We also thank the technicians

563 and students who helped conduct the Heliconia censuses and the BDFFP and INPA for

564 logistical support. Financial support was provided by the U.S. National Science Foundation

565 (awards DEB-0614339, DEB-0614149, INT 98-06351, and DEB-1948607). This is

566 publication No. _ in the BDFFP Technical Series. The authors delcare no conflicts of

567 interest.

568 Data Availability Statement

569 Data used in this study are available at the Dryad Digital Repository [links included upon

570 acceptance]; R code for analyses and visualizations are archived with Zenodo at

571 https://doi.org/10.5281/zenodo.5364591. 
bioRxiv preprint doi: https://doi.org/10.1101/2021.06.28.450186; this version posted September 20, 2021. The copyright holder for this preprint (which was not certified by peer review) is the author/funder, who has granted bioRxiv a license to display the preprint in perpetuity. It is made available under aCC-BY-NC-ND 4.0 International license. 


\section{Tables}

574 Table 1: Model intercepts and their 84\% confidence intervals. Non-overlapping confidence

575 intervals are bolded and can be interpreted as a significant difference in the vital rate

576 between continuous forest and 1 ha fragments.

\begin{tabular}{llr}
\hline vital rate & habitat & intercept \\
\hline survival & CF & $0.97[0.964,0.975]$ \\
& 1 ha & $0.962[0.957,0.966]$ \\
size & CF & $\mathbf{4 . 3 6}[\mathbf{4 . 3 1 3 , 4 . 4 0 8 ]}$ \\
& 1 ha & $\mathbf{4 . 1 8}[\mathbf{4 . 0 6 2 , 4 . 2 9 7 ]}$ \\
flowering & CF & $\mathbf{0 . 0 0 6}[\mathbf{0 . 0 0 5 , 0 . 0 0 9 ]}$ \\
& 1 ha & $\mathbf{0 . 0 0 2}[\mathbf{0 . 0 0 1}, \mathbf{0 . 0 0 4}]$
\end{tabular}

578 Table 2: Marginal hypothesis tests for models of survival probability, size, and flowering

579 probability of $H$. acuminata in continuous forest and 1 ha fragment plots. The adjusted $\mathrm{R}^{2}$ is

580 reported as a measure of model fit. The model terms included the parametric fixed effect

581 factor of whether plants flowered the previous year ("flowering"), the smoothed fixed

582 effect of plant size ("s(log( size $\left.\left._{t}\right)\right)$ ), the crossbasis smooth of lagged SPEI ("s(SPEI, lag)"),

583 and a random effect of plot ID, ("s(plot)"). Degrees of freedom are reported for the

584 parametric term, and estimated degrees of freedom (edf) are reproted for smooths. Larger

585 values for edf indicate more complex smooths and when edf is zero the term is effectively

586 dropped from the model. The test statistic reported is $\chi^{2}$ for survival and flowering and $F$

587 for $\log \left(\operatorname{size}_{t+1}\right)$.

\begin{tabular}{|c|c|c|c|c|c|c|}
\hline vital rate & habitat & $\mathrm{R}^{2}$ & term & (e)df & test statistic & $\mathrm{p}$-value \\
\hline \multirow[t]{2}{*}{ survival } & $\mathrm{CF}$ & 0.11 & flowering $_{t}$ & 1 & 0.14 & 0.709 \\
\hline & & & $s\left(\log \left(\operatorname{size}_{t}\right)\right)$ & 3.46 & $1,957.82$ & $<0.001$ \\
\hline
\end{tabular}




\begin{tabular}{|c|c|c|c|c|c|c|}
\hline & & & s(SPEI, lag) & 12.8 & 186.4 & $<0.001$ \\
\hline & & & $s($ plot $)$ & 4.34 & 37.83 & $<0.001$ \\
\hline & 1 ha & 0.06 & flowering $t_{t}$ & 1 & 1.64 & 0.200 \\
\hline & & & $s\left(\log \left(\operatorname{size}_{t}\right)\right)$ & 2.84 & 360.41 & $<0.001$ \\
\hline & & & s(SPEI, lag) & 10.78 & 73.09 & $<0.001$ \\
\hline & & & $s($ plot $)$ & 0 & 0 & 0.481 \\
\hline $\log \left(\operatorname{size}_{t+1}\right)$ & $\mathrm{CF}$ & 0.78 & flowering $_{t}$ & 1 & 3.74 & 0.053 \\
\hline & & & $s\left(\log \left(\operatorname{size}_{t}\right)\right)$ & 9.39 & $6,717.1$ & $<0.001$ \\
\hline & & & s(SPEI, lag) & 15.14 & 95.58 & $<0.001$ \\
\hline & & & $s($ plot $)$ & 4.08 & 7.04 & $<0.001$ \\
\hline & 1 ha & 0.7 & flowering $_{t}$ & 1 & 5.71 & 0.017 \\
\hline & & & $s\left(\log \left(\operatorname{size}_{t}\right)\right)$ & 4.19 & $3,006.2$ & $<0.001$ \\
\hline & & & s(SPEI, lag) & 18.18 & 27.04 & $<0.001$ \\
\hline & & & $s($ plot $)$ & 2.83 & 23.03 & $<0.001$ \\
\hline flowering $_{t+1}$ & $\mathrm{CF}$ & 0.19 & flowering $_{t}$ & 1 & 131.59 & $<0.001$ \\
\hline & & & $s\left(\log \left(\operatorname{size}_{t}\right)\right)$ & 5.8 & $1,748.08$ & $<0.001$ \\
\hline & & & s(SPEI, lag) & 11.45 & 415.26 & $<0.001$ \\
\hline & & & $s($ plot $)$ & 3.95 & 47.54 & $<0.001$ \\
\hline & 1 ha & 0.24 & flowering $_{t}$ & 1 & 38.76 & $<0.001$ \\
\hline & & & $s\left(\log \left(\operatorname{size}_{t}\right)\right)$ & 3.4 & 321.86 & $<0.001$ \\
\hline & & & s(SPEI, lag) & 14.13 & 120.82 & $<0.001$ \\
\hline & & & $s($ plot $)$ & 2.51 & 16.44 & $<0.001$ \\
\hline
\end{tabular}




\section{Figures}

a)

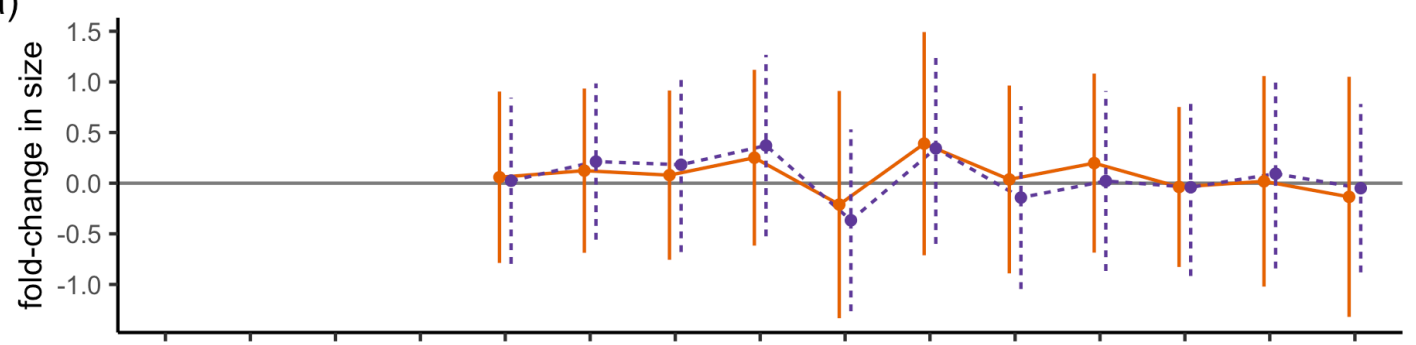

b)

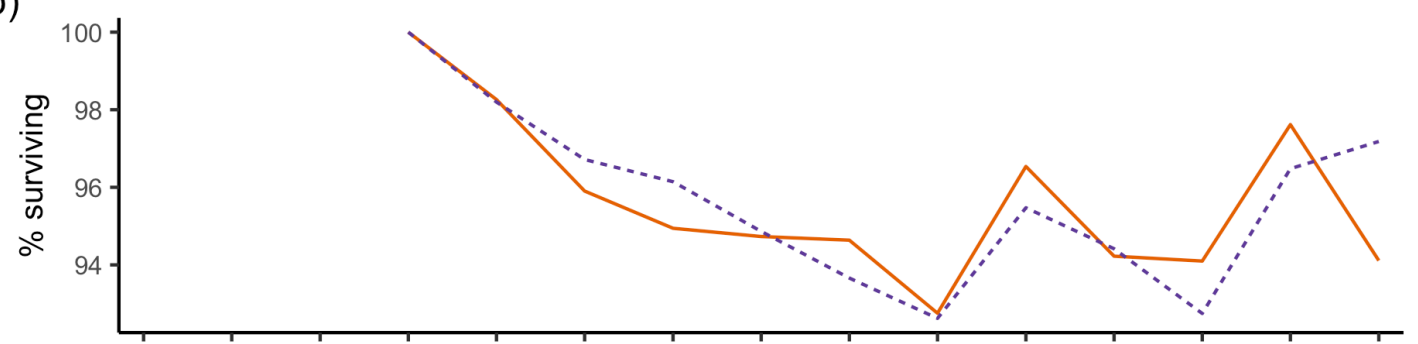

c)

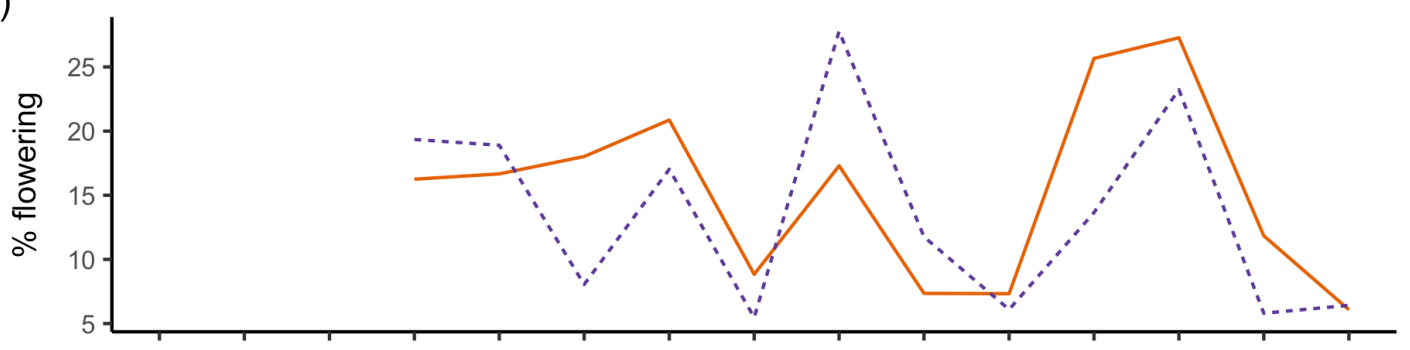

d)

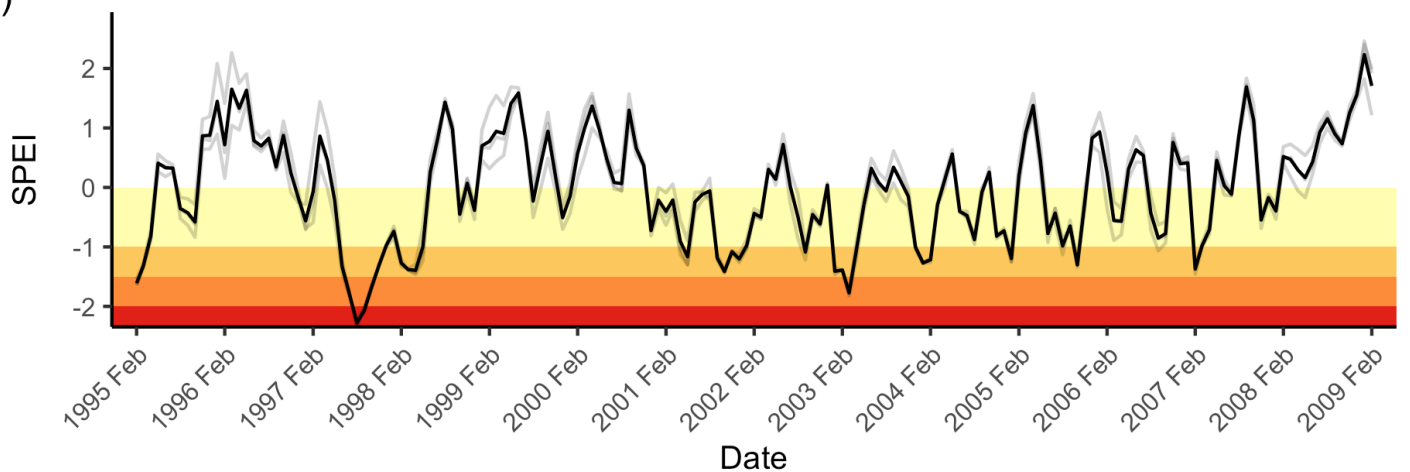

590 Figure 1: (a-c) Time series of $H$. acuminata vital rates in 1-ha fragments (solid orange lines)

591 and continuous forest (dashed blue lines) and (d) drought occurrence in the study region.

592 (a) Mean fold-change in plant plant size $\left(\log 2\left(\operatorname{size}_{t+1} /\right.\right.$ size $\left.\left._{t}\right)\right)$ varies by year and habitat. On

593 average, plants grew in most years with the notable exception in 2003, in which on average

594 plants regressed in size in both habitats (i.e., fold-change $<0$ ). Error bars represent the 
595 standard deviation. (b) The proportion of plants surviving from one transition year to the 596 next varied from 0.98 (CF in 1998-1999) to 0.93 (CF in 2003-2004). (c) The proportion of

597 H. acuminata above the size threshold for reproduction that flowered each year is on

598 average low but variable. The size threshold is determined by the upper 90th percentile

599 size of flowering plants across all years. (d) Monthly 3-month SPEI for our study region.

600 Gray lines represent values from different grid cells encompassing BDFFP; the dark line

601 represents the site mean. Colored stripes represent drought intensity: yellow = mild,

602 orange $=$ moderate, dark orange $=$ severe, red $=$ extreme

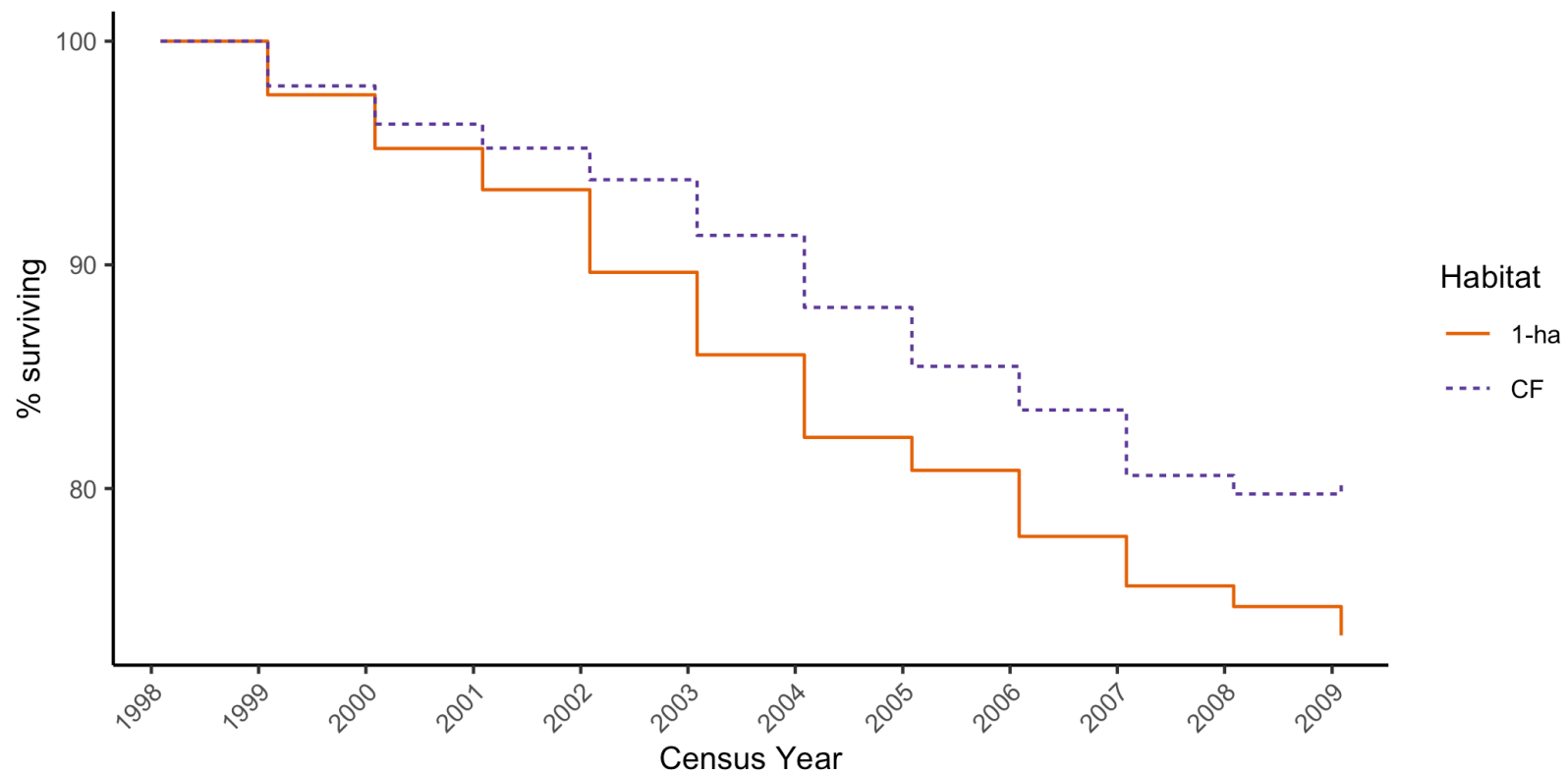

604 Figure 2: Survivorship curve for plants marked in the 1998 survey year; these plants

605 comprise $49 \%$ of those in the complete demographic dataset. The percentage of these

606 plants that were still alive ten years later was 79.7\% (1629/2055) in continuous forest

607 vs. 72.4\% (393/543) in 1-ha fragments. 
a)

b)
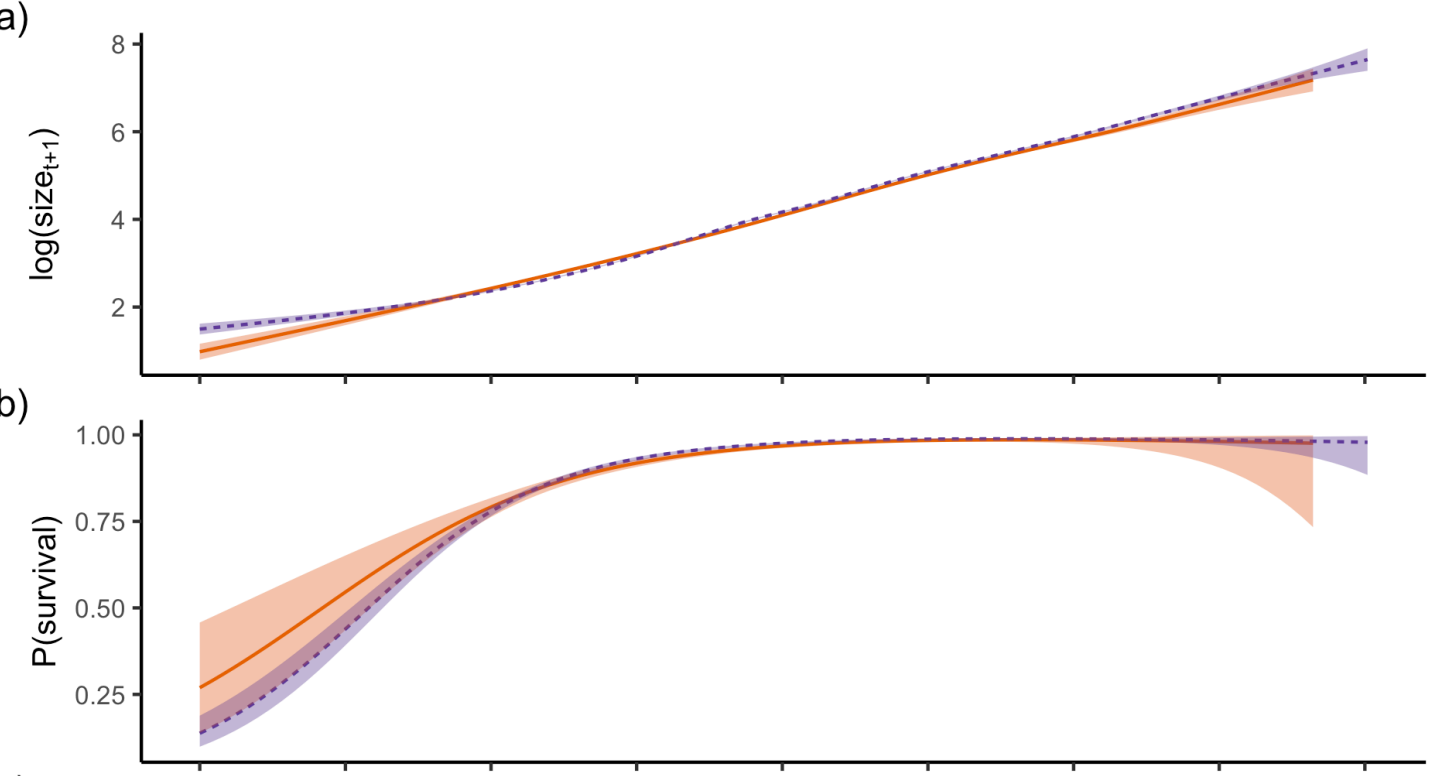

c)

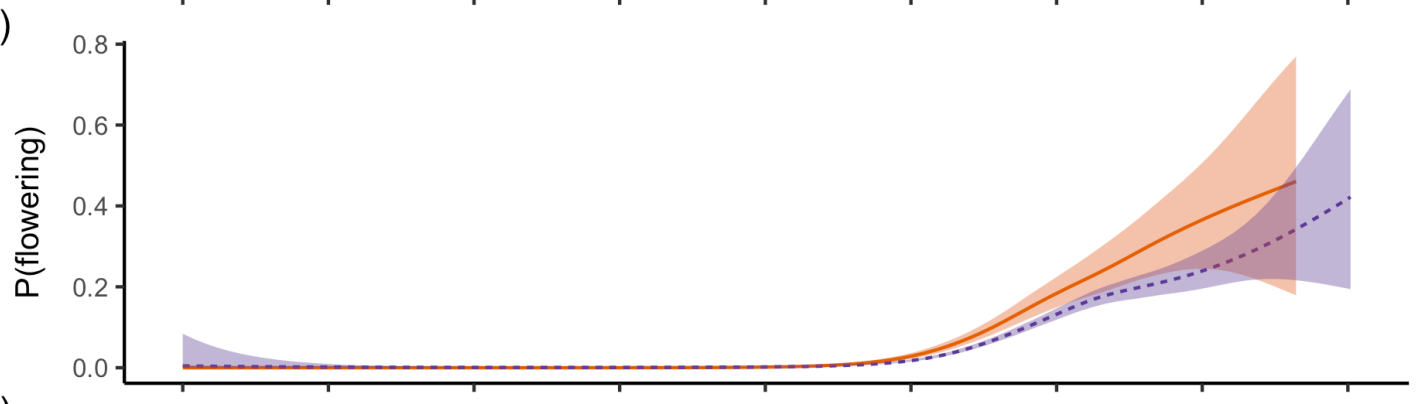

d)

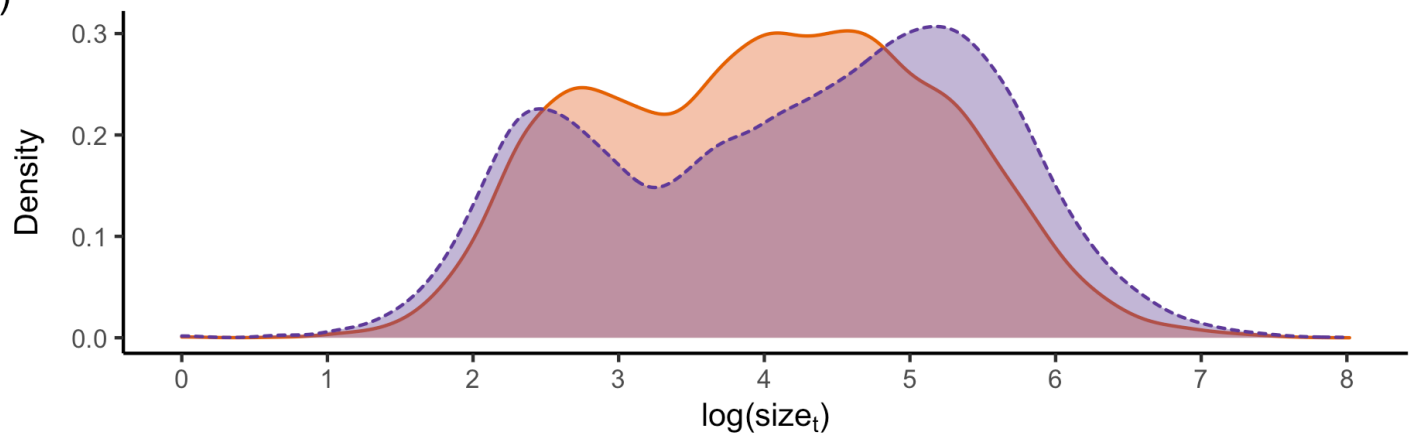

609 Figure 3: Marginal effect of plant size in the previous census on (a) survival, (b) $\log (\operatorname{size})$,

610 and (c) flowering probability. Plots a-c were created by evaluating the smooth functions of

$611 \log \left(\operatorname{size}_{t}\right)$ at observed values, adding the model intercepts, and back-transforming (when

612 appropriate) to the response scale (e.g. probability for a and c). The bands depicting the

$61395 \%$ confidence interval include uncertainty in the intercept and uncertainty due to

614 smoothness selection; the smooths for 1-ha fragments and continuous forest are fit in 
615 separate models. (d) Plant size distribution by habitat type (solid line = 1-ha fragments,

616 dashed line = Continuous Forest $)$. The curves in a-c are shown with raw data

617 superimposed in Figure S3.

a)

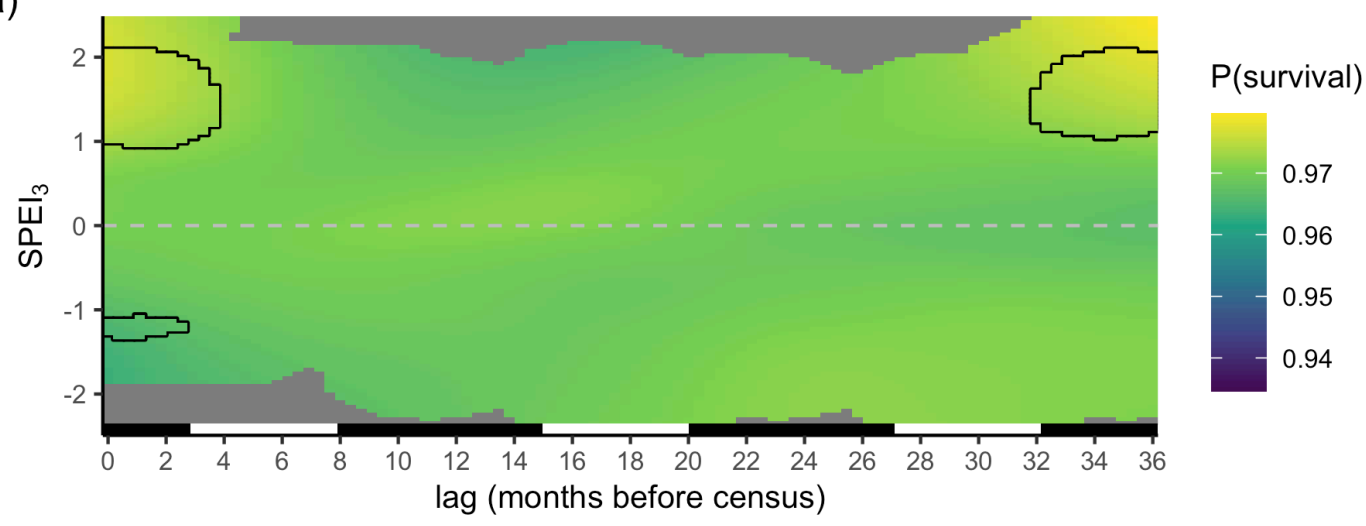

b)

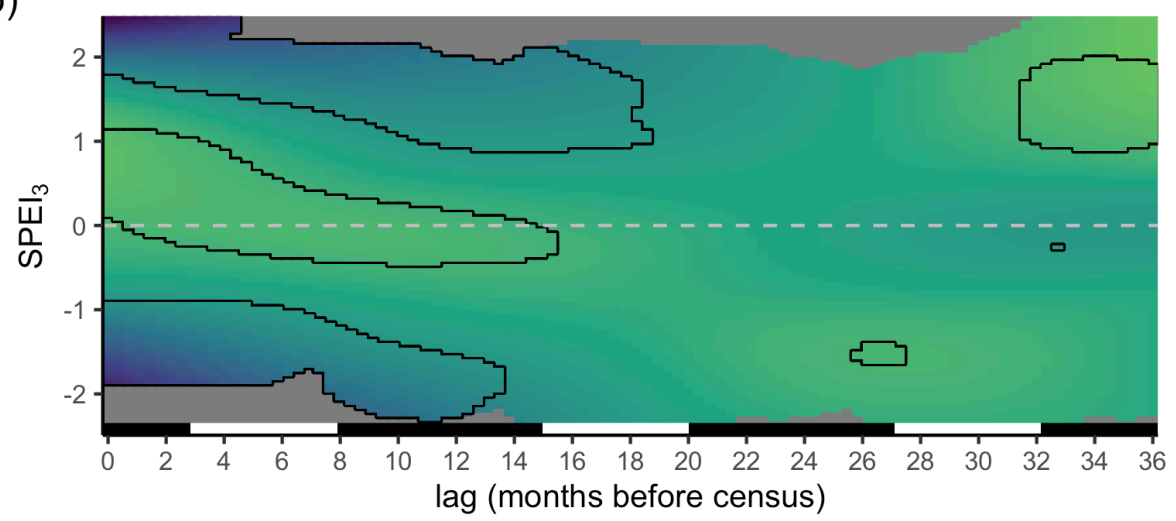

c)

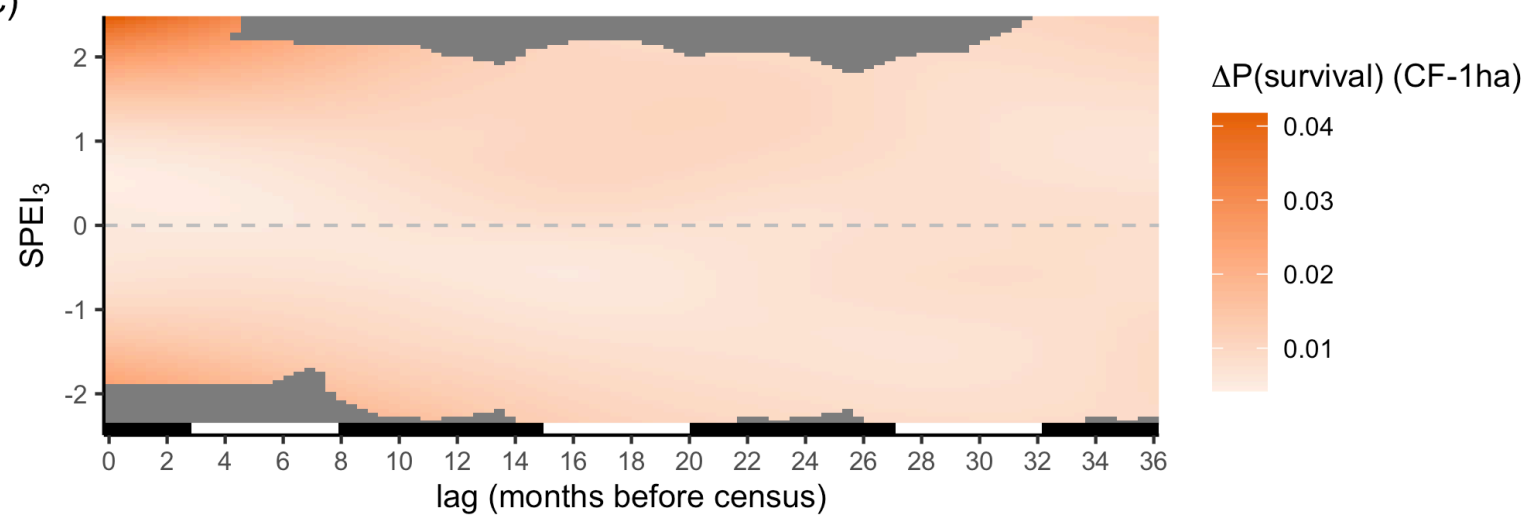

619 Figure 4: Marginal effect of lagged SPEI on H. acuminata survival in (a) continuous forest,

620 (b) 1-ha fragments, (c) and the difference between the two. Outlines show combinations of 
621 SPEI and lag time that have a significant effect on survival, defined as areas where the 95\%

622 confidence interval around the response does not overlap the intercept. The bar on the

623 bottom of each panel indicates wet seasons (black, November-May) and dry seasons

624 (white, June-October). For a and b, the model intercepts were added to the evaluated

625 crossbasis smooths and values were back-transformed to the response scale

626 (i.e. probabilities). Areas of the fitted smooth far from observed values (i.e. combinations of

627 lag time and SPEI) are shown in grey. 
a)

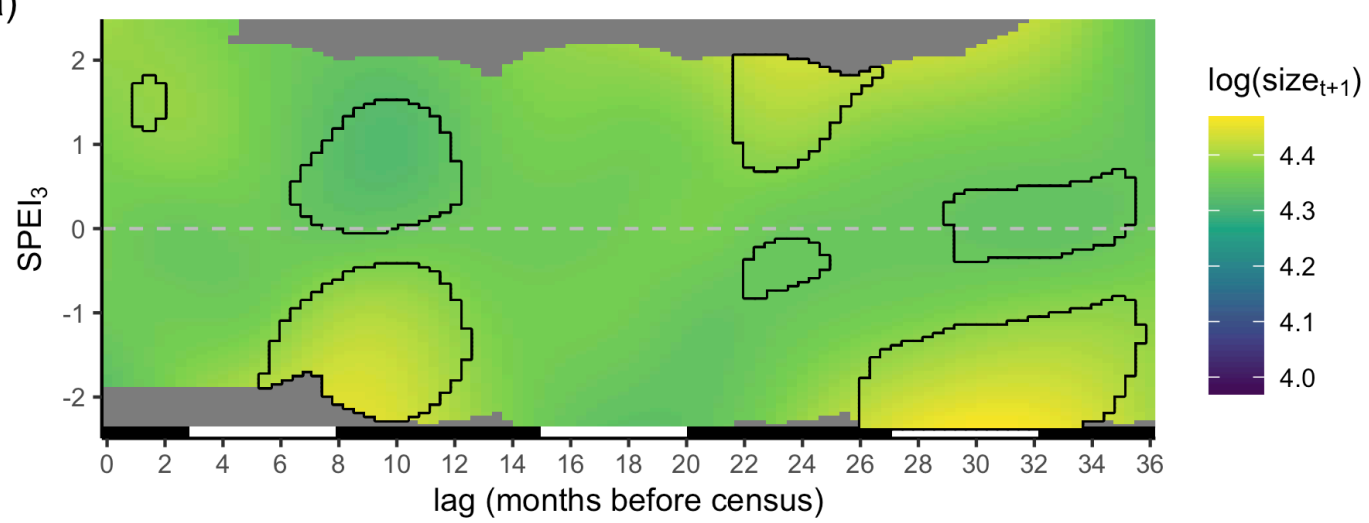

b)

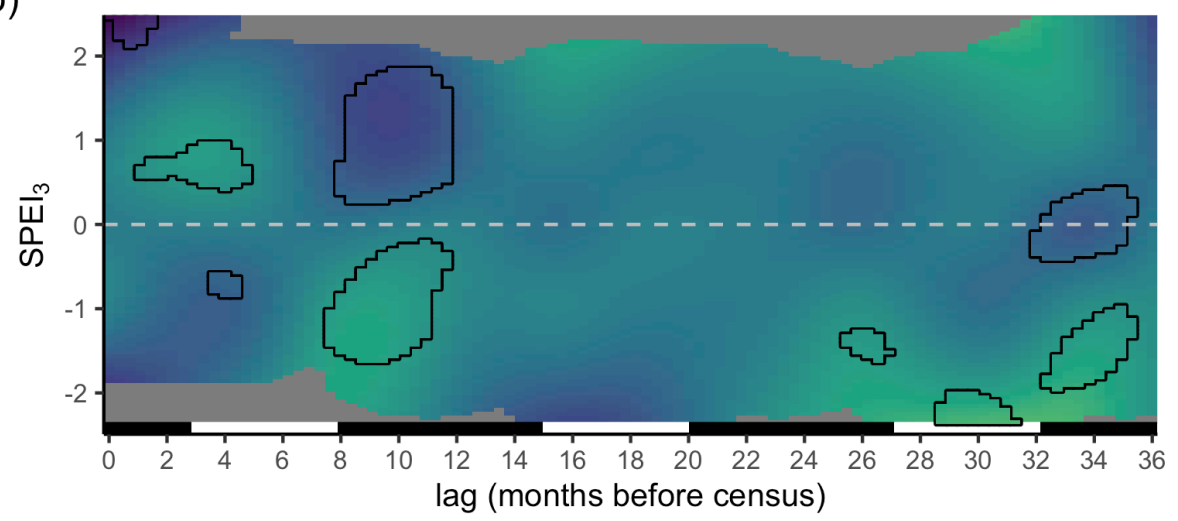

c)

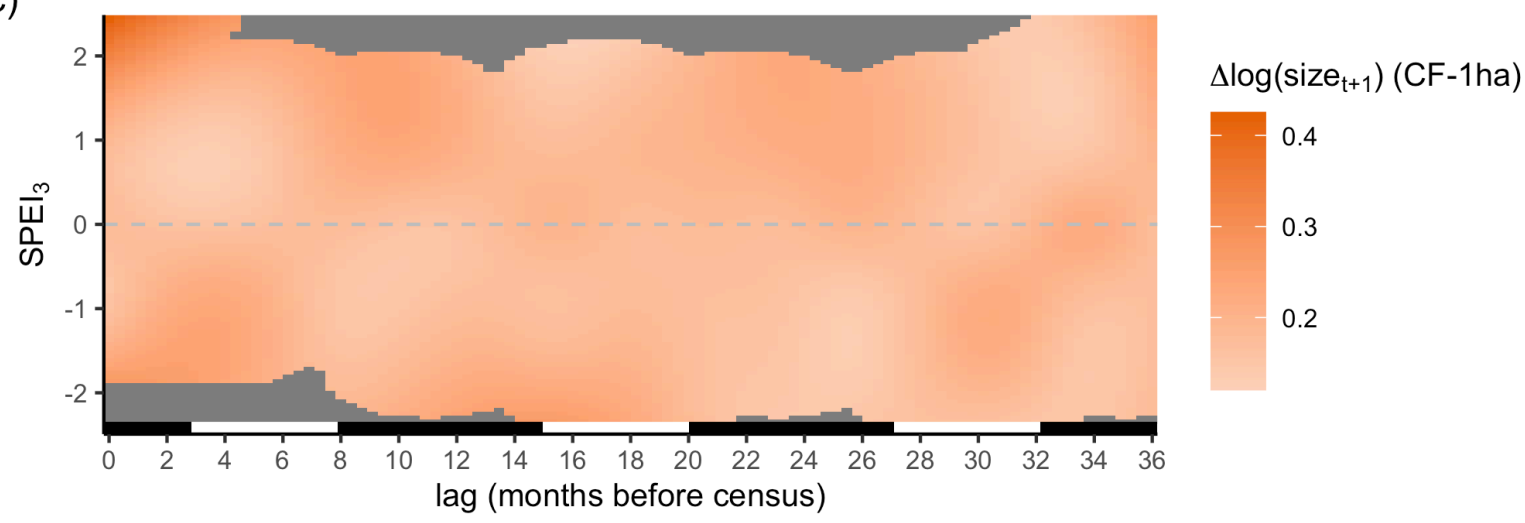

629 Figure 5: Marginal effect of lagged SPEI on H. acuminata size in (a) continuous forest, (b) 1-

630 ha fragments, (c) and the difference between the two. Outlines show combinations of SPEI

631 and lag time that have a significant effect on plant size, defined as areas where the $95 \%$

632 confidence interval around the response does not overlap the intercept. The bar on the

633 bottom of each panel indicates wet seasons (black, November-May) and dry seasons 
634 (white, June-October). For a and b, the model intercepts were added to the evaluated

635 crossbasis smooths. Areas of the fitted smooth far from observed values (i.e. combinations

636 of lag time and SPEI) are shown in grey.

a)

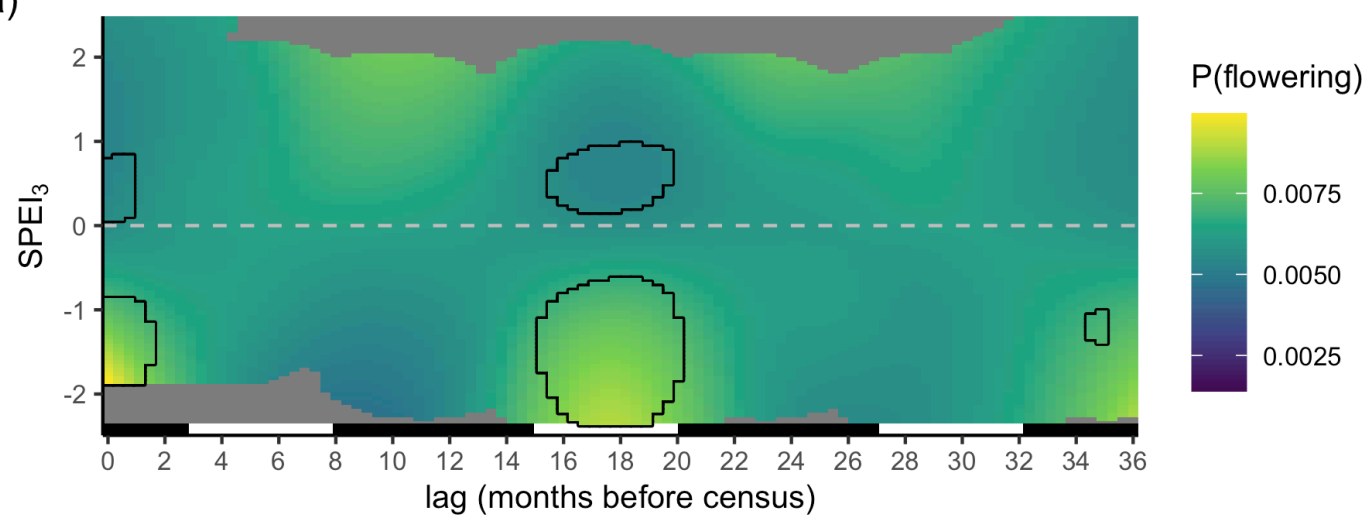

b)

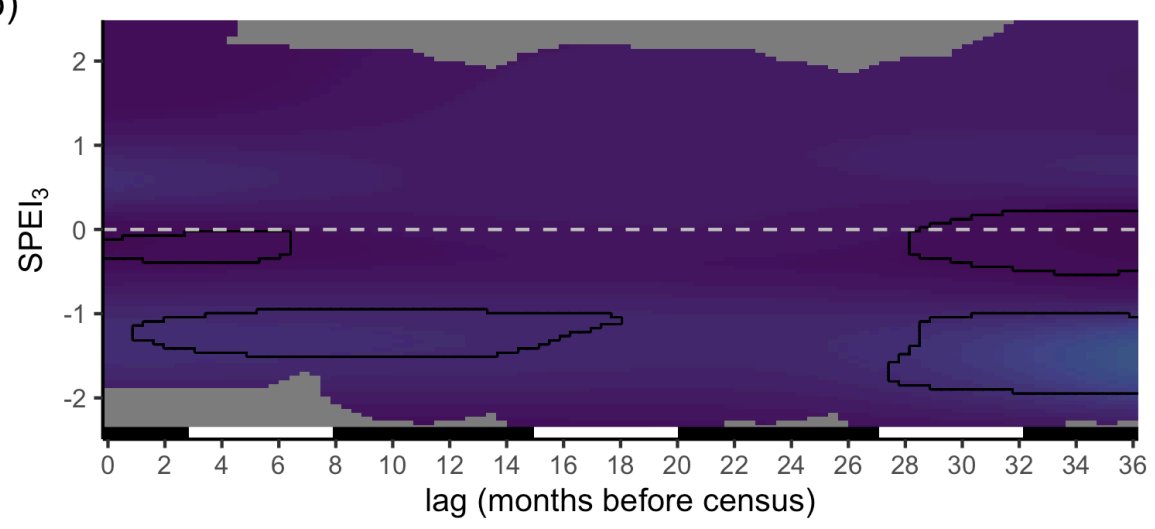

c)

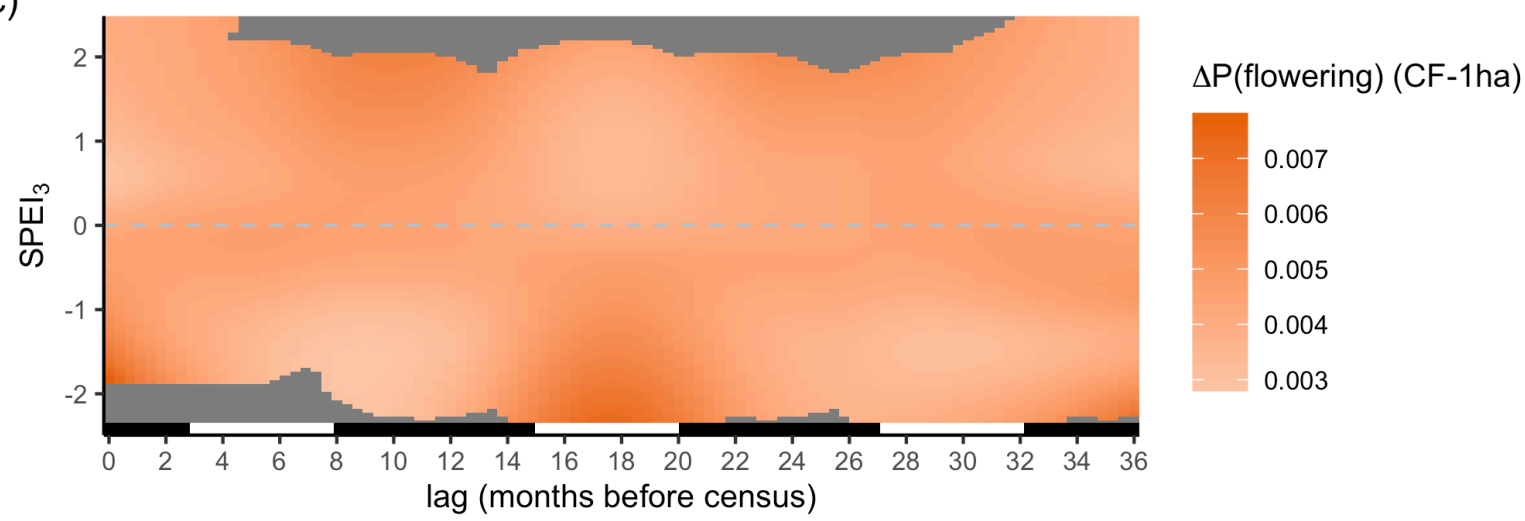

638 Figure 6: Marginal effect of lagged SPEI on H. acuminata flowering probability in (a)

639 continuous forest, (b) 1-ha fragments, (c) and the difference between the two. Outlines 
640 show combinations of SPEI and lag time that have a significant effect on probability of

641 flowering, defined as areas where the 95\% confidence interval around the response does

642 not overlap the intercept. The bar on the bottom of each panel indicates wet seasons (black,

643 November-May) and dry seasons (white, June-October). For a and b, the model intercepts

644 were added to the evaluated crossbasis smooths and values were back-transformed to the

645 response scale (i.e. probabilities). Areas of the fitted smooth far from observed values

646 (i.e. combinations of lag time and SPEI) are shown in grey.

\section{References}

648 Aguirre, B. A., Hsieh, B., Watson, S. J., \& Wright, A. J. (2021). The experimental manipulation 649 of atmospheric drought: Teasing out the role of microclimate in biodiversity experiments.

650 Journal of Ecology, 109(5), 1986-1999. https://doi.org/https://doi.org/10.1111/1365-

$651 \quad 2745.13595$

652 Alfaro-Sánchez, R., Muller-Landau, H. C., Wright, S. J., \& Camarero, J. J. (2017). Growth and 653 reproduction respond differently to climate in three Neotropical tree species. Oecologia, 654 184(2), 531-541. https://doi.org/10.1007/s00442-017-3879-3

655 Alroy, J. (2017). Effects of habitat disturbance on tropical forest biodiversity. Proceedings of 656 the National Academy of Sciences, 114(23), 6056-6061.

657 https://doi.org/10.1073/pnas.1611855114

658 Anderegg, W. R. L., Schwalm, C., Biondi, F., Camarero, J. J., Koch, G., Litvak, M., Ogle, K., Shaw, 659 J. D., Shevliakova, E., Williams, A. P., Wolf, A., Ziaco, E., \& Pacala, S. (2015). Pervasive 660 drought legacies in forest ecosystems and their implications for carbon cycle models. 661 Science, 349(6247), 528-532. https://doi.org/10.1126/science.aab1833

662 Arroyo-Rodríguez, V., Saldaña-Vázquez, R. A., Fahrig, L., \& Santos, B. A. (2017). Does forest 663 fragmentation cause an increase in forest temperature? Ecological Research, 32(1), 81-88. 664 https://doi.org/10.1007/s11284-016-1411-6

665 Beguería, S., \& Vicente-Serrano, S. M. (2017). SPEI: Calculation of the standardised 666 precipitation-evapotranspiration index. https://CRAN.R-project.org/package=SPEI

667 Betts, M. G., Wolf, C., Pfeifer, M., Banks-Leite, C., Arroyo-Rodríguez, V., Ribeiro, D. B., Barlow, 668 J., Eigenbrod, F., Faria, D., Fletcher, R. J., Hadley, A. S., Hawes, J. E., Holt, R. D., Klingbeil, B., 669 Kormann, U., Lens, L., Levi, T., Medina-Rangel, G. F., Melles, S. L., ... Ewers, R. M. (2019). 670 Extinction filters mediate the global effects of habitat fragmentation on animals. Science, 671 366(6470), 1236-1239. https://doi.org/10.1126/science.aax9387 
672 Bianchi, C. A., \& Haig, S. M. (2013). Deforestation trends of tropical dry forests in Central

673 Brazil. Biotropica, 45(3), 395-400. https://doi.org/https://doi.org/10.1111/btp.12010

674 Bierregaard, R. O., Gascon, C., Lovejoy, T. E., \& Mesquita, R. (Eds.). (2001). Lessons from

675 Amazonia: The ecology and conservation of a fragmented forest. Yale University Press.

676 Bierregaard, R. O., Lovejoy, T. E., Kapos, V., \& Hutchings, R. W. (1992). The biological

677 dynamics of tropical rainforest fragments. BioScience, 42(11), 859-866.

678 https://doi.org/10.2307/1312085

679 Broadbent, E. N., Asner, G. P., Keller, M., Knapp, D. E., Oliveira, P. J. C., \& Silva, J. N. (2008).

680 Forest fragmentation and edge effects from deforestation and selective logging in the

681 Brazilian Amazon. Biological Conservation, 141, 1745-1757.

682 https://doi.org/10.1016/j.biocon.2008.04.024

683 Brodie, J., Post, E., \& Laurance, W. F. (2012). Climate change and tropical biodiversity: A

684 new focus. Trends in Ecology \& Evolution, 27(3), 145-150.

685 https://doi.org/10.1016/j.tree.2011.09.008

686 Brooks, M. E., Kristensen, K., Darrigo, M. R., Rubim, P., Uriarte, M., Bruna, E. M., \& Bolker, B.

687 M. (2019). Statistical modeling of patterns in annual reproductive rates. Ecology, 100(7).

688 https://doi.org/10.1002/ecy.2706

689 Bruna, E. M. (1999). Seed germination in rainforest fragments. Nature, 402(6758), 139.

690 https://doi.org/10.1038/45963

691 Bruna, E. M. (2002). Effects of forest fragmentation on Heliconia acuminata seedling

692 recruitment in central Amazonia. Oecologia, 132(2), 235-243.

693 https://doi.org/10.1007/s00442-002-0956-y

694 Bruna, E. M. (2003). Are plant populations in fragmented habitats recruitment limited?

695 Tests with an Amazonian herb. Ecology, 84(4), 932-947. https://doi.org/10.1890/0012-

696 9658(2003)084[0932:APPIFH]2.0.CO;2

697 Bruna, E. M., Fiske, I. J., \& Trager, M. D. (2009). Habitat fragmentation and plant

698 populations: Is what we know demographically irrelevant? Journal of Vegetation Science,

699 20(3), 569-576. https://doi.org/10.1111/j.1654-1103.2009.01060.x

700 Bruna, E. M., \& Kress, W. J. (2002). Habitat fragmentation and the demographic structure of 701 an Amazonian understory herb (Heliconia acuminata). Conservation Biology, 16(5), 1256-

702 1266. https://doi.org/10.1046/j.1523-1739.2002.99494.x

703 Bruna, E. M., Kress, W. J., Marques, F., \& Silva, O. F. da. (2004). Heliconia acuminata

704 reproductive success is independent of local floral density. Acta Amazonica, 34(3), 467-

705 471. https://doi.org/10.1590/S0044-59672004000300012

706 Bruna, E. M., Nardy, O., Strauss, S. Y., \& Harrison, S. (2002). Experimental assessment of

707 Heliconia acuminata growth in a fragmented Amazonian landscape. Journal of Ecology,

708 90(4), 639-649. https://doi.org/10.1046/j.1365-2745.2002.00707.x 
Bruna, E. M., \& Oli, M. K. (2005). Demographic effects of habitat fragmentation on a tropical herb: Life-table response experiments. Ecology, 86(7), 1816-1824.

Bruna, E. M., \& Ribeiro, M. B. N. (2005). The compensatory responses of an understory herb to experimental damage are habitat-dependent. American Journal of Botany, 92(12), 21012210. https://doi.org/10.3732/ajb.92.12.2101 regimes beneath closed canopies and tree-fall gaps in temperate and tropical forests.

718 Compagnoni, A., Evers, S., \& Knight, T. M. (2021). Spatial replication provides substantial opportunities to estimate plant population responses to temporal climatic variation. Ecological Society of America Annual Meeting. B. (2004). Tropical forest dynamics across a rainfall gradient and the impact of an El Niño dry season. Journal of Tropical Ecology, 20(01), 51-72.

724 https://doi.org/10.1017/S0266467403001081

725 Connell, J. H., \& Green, P. T. (2000). Seedling dynamics over thirty-two years in a tropical 726 rain forest tree. Ecology, 81(2), 568-584.

727 Côrtes, M. C., Uriarte, M., Lemes, M. R., Gribel, R., Kress, W. J., Smouse, P. E., \& Bruna, E. M. (2013). Low plant density enhances gene dispersal in the Amazonian understory herb Heliconia Acuminata. Molecular Ecology, 22(22), 5716-5729.

731 Criley, R., \& Lekawatana, S. (1994). Year around production with high yields may be a possibility for Heliconia chartacea. Acta Horticulturae, 397, 95-102.

733 https://doi.org/10.17660/ActaHortic.1995.397.7

734 Crone, E. E., Menges, E. S., Ellis, M. M., Bell, T., Bierzychudek, P., Ehrlen, J., Kaye, T. N., Knight, T. M., Lesica, P., Morris, W. F., Oostermeijer, G., Quintana-Ascencio, P. F., Stanley, A., Ticktin, T., Valverde, T., \& Williams, J. L. (2011). How do plant ecologists use matrix population models? Ecology Letters, 14(1), 1-8. the Atlantic forest of northeast Brazil. Nature, 404(6773), 72-74.

740 https://doi.org/10.1038/35003563

741 Didham, R. K., Kapos, V., \& Ewers, R. M. (2012). Rethinking the conceptual foundations of habitat fragmentation research. Oikos, 121(2), 161-170. https://doi.org/10.1111/j.16000706.2011.20273.x 
747 Doak, D. F., \& Morris, W. F. (2010). Demographic compensation and tipping points in

748 climate-induced range shifts. Nature, 467(7318), 959-962.

749 Driscoll, D. A., Banks, S. C., Barton, P. S., Lindenmayer, D. B., \& Smith, A. L. (2013).

750 Conceptual domain of the matrix in fragmented landscapes. Trends in Ecology \& Evolution,

751 28(10), 605-613. https://doi.org/10.1016/j.tree.2013.06.010

752 Duffy, P. B., Brando, P., Asner, G. P., \& Field, C. B. (2015). Projections of future

753 meteorological drought and wet periods in the Amazon. Proceedings of the National

754 Academy of Sciences, 112(43), 13172-13177. https://doi.org/10.1073/pnas.1421010112

755 Edwards, W., \& Krockenberger, A. (2006). Seedling mortality due to drought and fire associated with the 2002 El Niño event in a tropical rain forest in north-east Queensland, Australia. Biotropica, 38(1), 16-26. https://doi.org/10.1111/j.1744-7429.2006.00098.x

758 Ehrlen, J., Morris, W. F., von Euler, T., \& Dahlgren, J. P. (2016). Advancing environmentally explicit structured population models of plants. Journal of Ecology, 104(2), 292-305. https://doi.org/10.1111/1365-2745.12523

761 Engelbrecht, B. M. J., Wright, S. J., \& De Steven, D. (2002). Survival and ecophysiology of tree 762 seedlings during El Niño drought in a tropical moist forest in Panama. Journal of Tropical 763 Ecology, 18, 569-579.

764 Espírito-Santo, F. D. B., Keller, M., Braswell, B., Nelson, B. W., Frolking, S., \& Vicente, G. (2010). Storm intensity and old-growth forest disturbances in the Amazon region. Geophysical Research Letters, 37(11). https://doi.org/10.1029/2010GL043146

767 Esquivel-Muelbert, A., Baker, T. R., Dexter, K. G., Lewis, S. L., Brienen, R. J. W., Feldpausch, T. R., Lloyd, J., Monteagudo-Mendoza, A., Arroyo, L., Álvarez-Dávila, E., Higuchi, N., Marimon, B. S., Marimon-Junior, B. H., Silveira, M., Vilanova, E., Gloor, E., Malhi, Y., Chave, J., Barlow, J., ... Phillips, O. L. (2019). Compositional response of Amazon forests to climate change. Global Change Biology, 25(1), 39-56. https://doi.org/10.1111/gcb.14413

772 Esteban, E. J. L., Castilho, C. V., Melgaço, K. L., \& Costa, F. R. C. (2021). The other side of droughts: Wet extremes and topography as buffers of negative drought effects in an Amazonian forest. New Phytologist, 229(4), 1995-2006. Compagnoni, A. (2021). Lagged and dormant season climate better predict plant vital rates than climate during the growing season. Global Change Biology, 27(9), 1927-1941. https://doi.org/10.1111/gcb.15519

780 Ewers, R. M., \& Banks-Leite, C. (2013). Fragmentation impairs the microclimate buffering effect of tropical forests. PLoS ONE, 8(3), e58093.

782 https://doi.org/10.1371/journal.pone.0058093 
distributions and diversity of Amazonian plant species. Global Change Biology, 18(8), 26362647. https://doi.org/10.1111/j.1365-2486.2012.02719.x

787 Gagnon, P. R., Bruna, E. M., Rubim, P., Darrigo, M. R., Littell, R. C., Uriarte, M., \& Kress, W. J. 788 (2011). Growth of an understory herb is chronically reduced in Amazonian forest fragments. Biological Conservation, 144(2), 830-835. https://doi.org/10.1016/j.biocon.2010.11.015

791 Gaoue, O. G., Horvitz, C. C., Steiner, U. K., \& Tuljapurkar, S. (2019). Climate, rather than human disturbance, is the main driver of age-specific mortality trajectories in a tropical tree. Ecological Modelling, 400, 34-40. https://doi.org/10.1016/j.ecolmodel.2019.03.007

794 Gasparrini, A. (2011). Distributed lag linear and non-linear models in R: The package dlnm. 795 Journal of Statistical Software, 43(8), 1-20. https://doi.org/10.18637/jss.v043.i08

796 Gasparrini, A., Scheipl, F., Armstrong, B., \& Kenward, M. G. (2017). A penalized framework for distributed lag non-linear models: Penalized DLNMs. Biometrics, 73(3), 938-948. https://doi.org/10.1111/biom.12645

Gentry, A. H., \& Dodson, C. (1987). Contribution of nontrees to species richness of a tropical rain forest. Biotropica, 19(2), 149-156. https://doi.org/10.2307/2388737

801 González-M, R., Posada, J. M., Carmona, C. P., Garzón, F., Salinas, V., Idárraga-Piedrahita, Á., Pizano, C., Avella, A., López-Camacho, R., Norden, N., Nieto, J., Medina, S. P., Rodríguez-M, G. M., Franke-Ante, R., Torres, A. M., Jurado, R., Cuadros, H., Castaño-Naranjo, A., García, H., \&

804 Salgado-Negret, B. (2020). Diverging functional strategies but high sensitivity to an

805 extreme drought in tropical dry forests. Ecology Letters, $n / a(n / a)$.

807 Haddad, N. M., Brudvig, L. A., Clobert, J., Davies, K. F., Gonzalez, A., Holt, R. D., Lovejoy, T. E., 808 Sexton, J. O., Austin, M. P., Collins, C. D., Cook, W. M., Damschen, E. I., Ewers, R. M., Foster, B. 809 L., Jenkins, C. N., King, A. J., Laurance, W. F., Levey, D. J., Margules, C. R., ... Townshend, J. R. 810 (2015). Habitat fragmentation and its lasting impact on Earth's ecosystems. Science 811 Advances, 1(2), e1500052. https://doi.org/10.1126/sciadv.1500052

812 Holyoak, M., \& Heath, S. K. (2016). The integration of climate change, spatial dynamics, and habitat fragmentation: A conceptual overview. Integrative Zoology, 11(1), 40-59.

814 https://doi.org/https://doi.org/10.1111/1749-4877.12167

815 Honnay, O., Verheyen, K., Butaye, J., Jacquemyn, H., Bossuyt, B., \& Hermy, M. (2002).

816 Possible effects of habitat fragmentation and climate change on the range of forest plant 817 species. Ecology Letters, 5(4), 525-530. https://doi.org/10.1046/j.1461-

818 0248.2002.00346.x

819 Huete, A. R., Didan, K., Shimabukuro, Y. E., Ratana, P., Saleska, S. R., Hutyra, L. R., Yang, W., 820 Nemani, R. R., \& Myneni, R. (2006). Amazon rainforests green-up with sunlight in dry 821 season. Geophysical Research Letters, 33(6). https://doi.org/10.1029/2005GL025583 
822 Janssen, T., van der Velde, Y., Hofhansl, F., Luyssaert, S., Naudts, K., Driessen, B., Fleischer,

823 K., \& Dolman, H. (2021). Drought effects on leaf fall, leaf flushing and stem growth in

824 Neotropical forest; reconciling remote sensing data and field observations. Biogeosciences

825 Discussions, 1-41. https://doi.org/10.5194/bg-2021-30

826 Jones, M. O., Kimball, J. S., \& Nemani, R. R. (2014). Asynchronous Amazon forest canopy

827 phenology indicates adaptation to both water and light availability. Environmental Research

828 Letters, 9(12), 124021. https://doi.org/10.1088/1748-9326/9/12/124021

829 Kannenberg, S. A., Schwalm, C. R., \& Anderegg, W. R. L. (2020). Ghosts of the past: How 830 drought legacy effects shape forest functioning and carbon cycling. Ecology Letters, 23(5), 831 891-901. https://doi.org/10.1111/ele.13485

832 Klimešová, J., Martínková, J., \& Ottaviani, G. (2018). Belowground plant functional ecology:

833 Towards an integrated perspective. Functional Ecology, 32(9), 2115-2126.

834 https://doi.org/10.1111/1365-2435.13145

835 Kress, W. J. (1990). The diversity and distribution of Heliconia (Heliconiaceae) in Brazil.

836 Acta Botanica Brasileira, 4(1), 159-167.

837 Landau, W. M. (2021). The targets R package: A dynamic Make-like function-oriented 838 pipeline toolkit for reproducibility and high-performance computing. Journal of Open

839 Source Software, 6(57), 2959. https://doi.org/ghwrqs

840 Laurance, W. F., Andrade, A. S., Magrach, A., Camargo, J. L. C., Campbell, M., Fearnside, P. M., 841 Edwards, W., Valsko, J. J., Lovejoy, T. E., \& Laurance, S. G. (2014). Apparent environmental 842 synergism drives the dynamics of Amazonian forest fragments. Ecology, 95(11), 3018843 3026. https://doi.org/10.1890/14-0330.1

844 Laurance, W. F., Ferreira, L. V., Rankin de Merona, J. M., \& Laurance, S. G. (1998). Rain forest 845 fragmentation and the dynamics of Amazonian tree communities. Ecology, 79(6), 20328462040.

847 Laurance, W. F., Nascimento, H. E. M., Laurance, S. G., Andrade, A., Ribeiro, J. E. L. S., Giraldo, 848 J. P., Lovejoy, T. E., Condit, R., Chave, J., Harms, K. E., \& D’Angelo, S. (2006). Rapid decay of 849 tree-community composition in Amazonian forest fragments. Proceedings of the National 850 Academy of Sciences, 103(50), 19010-19014. https://doi.org/10.1073/pnas.0609048103

851 Laurance, W. F., \& Williamson, G. B. (2001). Positive feedbacks among forest fragmentation, 852 drought, and climate change in the Amazon. Conservation Biology, 15(6), 1529-1535.

853 https://doi.org/10.1046/j.1523-1739.2001.01093.x

854 Laurance, W. F., Williamson, G. B., Delamônica, P., Oliveira, A., Lovejoy, T. E., Gascon, C., \& 855 Pohl, L. (2001). Effects of a strong drought on Amazonian forest fragments and edges. 856 Journal of Tropical Ecology, 17(6), 771-785.

857 Leitold, V., Morton, D. C., Longo, M., dos-Santos, M. N., Keller, M., \& Scaranello, M. (2018). El 858 Niño drought increased canopy turnover in Amazon forests. New Phytologist, 219(3), 959-

859 971. https://doi.org/10.1111/nph.15110 
860 Lewis, S. L., Brando, P. M., Phillips, O. L., Heijden, G. M. F. van der, \& Nepstad, D. (2011). The 8612010 Amazon Drought. Science, 331(6017), 554-554.

862 https://doi.org/10.1126/science.1200807

863 Marengo, J. A., Nobre, C. A., Tomasella, J., Oyama, M. D., Sampaio de Oliveira, G., de Oliveira, 864 R., Camargo, H., Alves, L. M., \& Brown, I. F. (2008). The drought of Amazonia in 2005.

865 Journal of Climate, 21(3), 495-516. https://doi.org/10.1175/2007JCLI1600.1

866 Markewitz, D., Devine, S., Davidson, E. A., Brando, P., \& Nepstad, D. C. (2010). Soil moisture depletion under simulated drought in the Amazon: impacts on deep root uptake. New

868 Phytologist, 187(3), 592-607. https://doi.org/10.1111/j.1469-8137.2010.03391.x

869 Marra, G., \& Wood, S. N. (2011). Practical variable selection for generalized additive models. 870 Computational Statistics \& Data Analysis, 55(7), 2372-2387.

871 https://doi.org/10.1016/j.csda.2011.02.004

872 McKee, T. B., Doesken, N. J., Kleist, J., \& others. (1993). The relationship of drought 873 frequency and duration to time scales. Proceedings of the 8th Conference on Applied 874 Climatology, 17, 179-183.

875 McPhaden, M. J. (1999). The child prodigy of 1997-98. Nature, 398(6728), 559-561.

876 https://doi.org/10.1038/19193

877 Molowny-Horas, R., Suarez, M. L., \& Lloret, F. (2017). Changes in the natural dynamics of 878 Nothofagus Dombeyi forests: Population modeling with increasing drought frequencies. 879 Ecosphere, 8(3), e01708. https://doi.org/10.1002/ecs2.1708

880 Morris, W. F., \& Doak, D. F. (2002). Quantitative conservation biology: Theory and practice of 881 population viability analysis. Sinauer.

882 Morris, W. F., Pfister, C. A., Tuljapurkar, S., Haridas, C. V., Boggs, C. L., Boyce, M. S., Bruna, E. 883 M., Church, D. R., Coulson, T., Doak, D. F., Forsyth, S., Gaillard, J.-M., Horvitz, C. C., Kalisz, S., 884 Kendall, B. E., Knight, T. M., Lee, C. T., \& Menges, E. S. (2008). Longevity can buffer plant and 885 animal populations against changing climatic variability. Ecology, 89(1), 19-25.

886 https://doi.org/10.1890/07-0774.1

887 Mundim, F. M., \& Bruna, E. M. (2016). Is there a temperate bias in our understanding of how 888 climate change will alter plant-herbivore interactions? A meta- analysis of experimental 889 studies. American Naturalist, 188, S74-S89.

890 Nakazono, E. M., Bruna, E. M., \& Mesquita, R. C. G. (2004). Experiemental harvesting of the 891 non-timber forest product Ischnosiphon polyphyllus in central Amazonia. Forest Ecology and 892 Management, 190(2-3), 219-225. https://doi.org/10.1016/j.foreco.2003.10.013

893 Negrón-Juárez, R. I., Holm, J. A., Marra, D. M., Rifai, S. W., Riley, W. J., Chambers, J. Q., Koven, 894 C. D., Knox, R. G., McGroddy, M. E., Vittorio, A. V. D., Urquiza-Muñoz, J., Tello-Espinoza, R., 895 Muñoz, W. A., Ribeiro, G. H. P. M., \& Higuchi, N. (2018). Vulnerability of Amazon forests to 896 storm-driven tree mortality. Environmental Research Letters, 13(5), 054021.

897 https://doi.org/10.1088/1748-9326/aabe9f 
Ogle, K., Barber, J. J., Barron-Gafford, G. A., Bentley, L. P., Young, J. M., Huxman, T. E., Loik, M. E., \& Tissue, D. T. (2015). Quantifying ecological memory in plant and ecosystem processes. Ecology Letters, 18(3), 221-235. https://doi.org/10.1111/ele.12399

901 Oliver, T. H., Marshall, H. H., Morecroft, M. D., Brereton, T., Prudhomme, C., \& Huntingford, C. 902 (2015). Interacting effects of climate change and habitat fragmentation on droughtsensitive butterflies. Nature Climate Change, 5(10), 941-945. https://doi.org/10.1038/nclimate2746

905 Opdam, P., \& Wascher, D. (2004). Climate change meets habitat fragmentation: Linking landscape and biogeographical scale levels in research and conservation. Biological Conservation, 117(3), 285-297.

908 Paniw, M., James, T. D., Ruth Archer, C., Römer, G., Levin, S., Compagnoni, A., Che-Castaldo, J., Bennett, J. M., Mooney, A., Childs, D. Z., Ozgul, A., Jones, O. R., Burns, J. H., Beckerman, A. P., Patwary, A., Sanchez-Gassen, N., Knight, T. M., \& Salguero-Gómez, R. (2021). The myriad of complex demographic responses of terrestrial mammals to climate change and gaps of

912

913 knowledge: A global analysis. Journal of Animal Ecology. https://doi.org/10.1111/13652656.13467

Parent, C., Nicolas, C., Audrey, B., Crevècoeur, M., \& Dat, J. (2008). An overview of plant responses to soil waterlogging. Plant Stress, 2(1), 20-27. Wright, S. (2013). Clouds and temperature drive dynamic changes in tropical flower production. Nature Climate Change, 3(9), 838-842. https://doi.org/10.1038/nclimate1934

919 Payton, M. E., Greenstone, M. H., \& Schenker, N. (2003). Overlapping confidence intervals or 920 standard error intervals: What do they mean in terms of statistical significance? Journal of 921 Insect Science, 3(34), 1-6. https://doi.org/10.1673/031.003.3401

922 Pedersen, T. L. (2020). Patchwork: The composer of plots [Manual].

923 Phillips, O. L., Aragao, L. E. O. C., Lewis, S. L., Fisher, J. B., Lloyd, J., Lopez-Gonzalez, G., Malhi, 924 Y., Monteagudo, A., Peacock, J., Quesada, C. A., van der Heijden, G., Almeida, S., Amaral, I., 925 Arroyo, L., Aymard, G., Baker, T. R., Banki, O., Blanc, L., Bonal, D., ... Torres-Lezama, A. (2009). Drought sensitivity of the Amazon rainforest. Science, 323(5919), 1344-1347.

928 Phillips, O. L., van der Heijden, G., Lewis, S. L., López-González, G., Aragão, L. E. O. C., Lloyd, J., 929 Malhi, Y., Monteagudo, A., Almeida, S., Dávila, E. A., Amaral, I., Andelman, S., Andrade, A., 930 Arroyo, L., Aymard, G., Baker, T. R., Blanc, L., Bonal, D., de Oliveira, Á. C. A., ... Vilanova, E. 931 (2010). Drought-mortality relationships for tropical forests. New Phytologist, 187(3), 631932 646. https://doi.org/10.1111/j.1469-8137.2010.03359.x

933 Pumisutapon, P., Visser, R. G. F., \& de Klerk, G.-J. (2012). Moderate abiotic stresses increase 934 rhizome growth and outgrowth of axillary buds in Alstroemeria cultured in vitro. Plant Cell, 
935 Tissue and Organ Culture (PCTOC), 110(3), 395-400. https://doi.org/10.1007/s11240-012-

$936 \quad 0160-7$

937 R Core Team. (2020). R: A language and environment for statistical computing.

938 Rankin-de-Mérona, J. M., Prance, G. T., Hutchings, R. W., da Silva, M. F., Rodrigues, W. A., \&

939 Uehling, M. E. (1992). Preliminary results of a large-scale tree inventory of upland rain

940 forest in the central Amazon. Acta Amazonica, 22(4), 493-534.

941 https://doi.org/10.1590/1809-43921992224534

942 Ribeiro, M. B. N., Bruna, E. M., \& Mantovani, W. (2010). Influence of post-clearing treatment

943 on the recovery of herbaceous plant communities in Amazonian secondary forests.

944 Restoration Ecology, 18, 50-58.

945 Rundel, P. W., Cooley, A. M., Gerst, K. L., Riordan, E. C., Sharifi, M. R., Sun, J. W., \& Tower, J. A.

946 (2020). Functional traits of broad-leaved monocot herbs in the understory and forest edges

947 of a Costa Rican rainforest. PeerJ, 8, e9958. https://doi.org/10.7717/peerj.9958

948 Rundel, P. W., Sharifi, M. R., Gibson, A. C., \& Esler, K. J. (1998). Structural and physiological

949 adaptation to light environments in Neotropical Heliconia (Heliconiaceae). Journal of

950 Tropical Ecology, 14(6), 789-801. https://doi.org/10.1017/S0266467498000571

951 Salguero-Gómez, R., Jones, O. R., Archer, C. R., Buckley, Y. M., Che-Castaldo, J., Caswell, H.,

952 Hodgson, D., Scheuerlein, A., Conde, D. A., Brinks, E., Buhr, H., Farack, C., Gottschalk, F.,

953 Hartmann, A., Henning, A., Hoppe, G., Römer, G., Runge, J., Ruoff, T., ... Vaupel, J. W. (2015).

954 The COMPADRE Plant Matrix Database: An open online repository for plant demography.

955 Journal of Ecology, 103(1), 202-218. https://doi.org/10.1111/1365-2745.12334

956 Sapsford, S. J., Paap, T., Hardy, G. E. St. J., \& Burgess, T. I. (2017). The 'chicken or the egg':

957 Which comes first, forest tree decline or loss of mycorrhizae? Plant Ecology, 218(9), 1093-

958 1106. https://doi.org/10.1007/s11258-017-0754-6

959 Scariot, A. (1999). Forest fragmentation effects on palm diversity in central Amazonia.

960 Journal of Ecology, 87(1), 66-76. https://doi.org/10.1046/j.1365-2745.1999.00332.x

961 Scariot, A. (2000). Seedling Mortality by Litterfall in Amazonian Forest Fragments.

962 Biotropica, 32, 662-669. https://doi.org/10.1111/j.1744-7429.2000.tb00513.x

963 Scheffers, B. R., Edwards, D. P., Macdonald, S. L., Senior, R. A., Andriamahohatra, L. R.,

964 Roslan, N., Rogers, A. M., Haugaasen, T., Wright, P., \& Williams, S. E. (2017). Extreme

965 thermal heterogeneity in structurally complex tropical rain forests. Biotropica, 49(1), 35-

966 44. https://doi.org/10.1111/btp.12355

967 Schwalm, C. R., Anderegg, W. R. L., Michalak, A. M., Fisher, J. B., Biondi, F., Koch, G., Litvak, 968 M., Ogle, K., Shaw, J. D., Wolf, A., Huntzinger, D. N., Schaefer, K., Cook, R., Wei, Y., Fang, Y.,

969 Hayes, D., Huang, M., Jain, A., \& Tian, H. (2017). Global patterns of drought recovery. Nature,

970 548(7666), 202-205. https://doi.org/10.1038/nature23021 
Schwartz, N. B., Budsock, A. M., \& Uriarte, M. (2019). Fragmentation, forest structure, and topography modulate impacts of drought in a tropical forest landscape. Ecology, 100(6),

973 e02677. https://doi.org/10.1002/ecy.2677

974 Scott, E. R., Wei, J.-P., Li, X., Han, W.-Y., \& Orians, C. M. (2021). Differing non-linear, lagged

975 effects of temperature and precipitation on an insect herbivore and its host plant.

976 Ecological Entomology, early view. https://doi.org/10.1111/een.13023

977 Selwood, K. E., McGeoch, M. A., \& Nally, R. M. (2015). The effects of climate change and landuse change on demographic rates and population viability. Biological Reviews, 90(3), 837853. https://doi.org/10.1111/brv.12136

980 Silva Junior, C. H. L., Pessôa, A. C. M., Carvalho, N. S., Reis, J. B. C., Anderson, L. O., \& Aragão, 981 L. E. O. C. (2021). The Brazilian Amazon deforestation rate in 2020 is the greatest of the 982 decade. Nature Ecology \& Evolution, 5(2), 144-145. https://doi.org/10.1038/s41559-020983 01368-X

984 Simpson, G. L. (2021). Gratia: Graceful 'ggplot'-Based graphics and other functions for GAMs 985 fitted using 'mgcv' [Manual].

986 Sletvold, N. (2005). Density-dependent growth and survival in a natural population of the facultative biennial Digitalis purpurea. Journal of Ecology, 93(4), 727-736.

988 https://doi.org/10.1111/j.1365-2745.2005.01008.x

989 Snow, D. W. (1981). Tropical frugivorous birds and their food plants - a world survey.

990 Biotropica, 13(1), 1-14. https://doi.org/10.2307/2387865

991 Ssali, F., Moe, S. R., \& Sheil, D. (2019). Damage to artificial seedlings across a disturbed 992 Afromontane forest landscape. Biotropica, 51(5), 652-663.

993 https://doi.org/https://doi.org/10.1111/btp.12703

994 Stiles, F. G. (1975). Ecology, flowering phenology, and hummingbird pollination of some 995 Costa Rican Heliconia species. Ecology, 56(2), 285-301. https://doi.org/10.2307/1934961

996 Stouffer, P. C., \& Bierregaard, R. O. (1996). Forest fragmentation and seasonal patterns of 997 hummingbird abundance in Amazonian Brazil. Ararajuba, 4(1), 9-14.

998 Taubert, F., Fischer, R., Groeneveld, J., Lehmann, S., Müller, M. S., Rödig, E., Wiegand, T., \& 999 Huth, A. (2018). Global patterns of tropical forest fragmentation. Nature, 554(7693), 5191000 522. https://doi.org/10.1038/nature25508

1001 Teller, B. J., Adler, P. B., Edwards, C. B., Hooker, G., \& Ellner, S. P. (2016). Linking 1002 demography with drivers: Climate and competition. Methods in Ecology and Evolution, 7(2), 1003 171-183. https://doi.org/10.1111/2041-210X.12486

1004 Tenhumberg, B., Crone, E. E., Ramula, S., \& Tyre, A. J. (2018). Time-lagged effects of weather 1005 on plant demography: Drought and Astragalus scaphoides. Ecology, 99(4), 915-925.

1006 https://doi.org/10.1002/ecy.2163 
1007 Ticktin, T. (2003). Relationships between El Niño Southern Oscillation and demographic 1008 patterns in a substitute food for collared peccaries in Panama. Biotropica, 35(2), 189-197.

1009 https://doi.org/10.1111/j.1744-7429.2003.tb00278.x

1010 Uriarte, M., Anciães, M., da Silva, M. T. B., Rubim, R., Johnson, E., \& Bruna, E. M. (2011).

1011 Disentangling the drivers of reduced long-distance seed dispersal by birds in an experimentally fragmented landscape. Ecology, 92(4), 924-937.

1013 https://doi.org/10.1890/10-0709.1

1014 Uriarte, M., Bruna, E. M., Rubim, P., Anciães, M., \& Jonckheere, I. (2010). Effects of forest 1015 fragmentation on the seedling recruitment of a tropical herb: assessing seed vs. safe-site 1016 limitation. Ecology, 91(5), 1317-1328. https://doi.org/10.1890/09-0785.1

1017 Uriarte, M., Muscarella, R., \& Zimmerman, J. K. (2018). Environmental heterogeneity and 1018 biotic interactions mediate climate impacts on tropical forest regeneration. Global Change 1019 Biology, 24(2), e692-e704. https://doi.org/10.1111/gcb.14000

1020 Uriarte, M., Schwartz, N., Powers, J. S., Marín-Spiotta, E., Liao, W., \& Werden, L. K. (2016). Impacts of climate variability on tree demography in second growth tropical forests: The importance of regional context for predicting successional trajectories. Biotropica, 48(6),

1023 780-797. https://doi.org/10.1111/btp.12380

1024 van de Pol, M., Bailey, L. D., McLean, N., Rijsdijk, L., Lawson, C. R., \& Brouwer, L. (2016). 1025 Identifying the best climatic predictors in ecology and evolution. Methods in Ecology and Evolution, 7(10), 1246-1257. https://doi.org/10.1111/2041-210X.12590

1027 Vasconcelos, H. L., \& Luizão, F. J. (2004). Litter production and litter nutrient concentrations in a fragmented Amazonian landscape. Ecological Applications, 14(3), 884892. https://doi.org/10.1890/03-5093

1030 Vicente-Serrano, S. M., Beguería, S., \& López-Moreno, J. I. (2010). A multiscalar drought 1031 index sensitive to global warming: The standardized precipitation evapotranspiration 1032 index. Journal of Climate, 23(7), 1696-1718. https://doi.org/10.1175/2009JCLI2909.1

1033 Westerband, A. C., Horvitz, C. C., \& Gilliam, F. (2017). Early life conditions and precipitation influence the performance of widespread understorey herbs in variable light

10362745.12757

1037 Wickham, H. (2016). Ggplot2: Elegant graphics for data analysis. Springer-Verlag New York.

1038 Williams, J. L., Jacquemyn, H., Ochocki, B. M., Brys, R., Miller, T. E. X., \& Shefferson, R. (2015). Life history evolution under climate change and its influence on the population dynamics of a long-lived plant. Journal of Ecology, 103(4), 798-808. https://doi.org/10.1111/1365-

10412745.12369

1042 Williamson, G. B., Laurance, W. F., Oliveira, A. A., Delamônica, P., Gascon, C., Lovejoy, T. E., \& 1043 Pohl, L. (2000). Amazonian tree mortality during the 1997 El Niño drought. Conservation 1044 Biology, 14(5), 1538-1542. https://doi.org/10.1046/j.1523-1739.2000.99298.x 
1045 Wood, S. N. (2017). Generalized additive models: An introduction with $R$ (Second edition).

1046 CRC Press/Taylor \& Francis Group.

1047 Wright, S. J. (1992). Seasonal drought, soil fertility and the species density of tropical forest 1048 plant communities. Trends in Ecology \& Evolution, 7(8), 260-263.

1049 https://doi.org/10.1016/0169-5347(92)90171-7

1050 Wright, S. J., \& Calderon, O. (2006). Seasonal, El Niño and longer term changes in flower and 1051 seed production in a moist tropical forest. Ecology Letters, 9(1), 35-44.

1052 https://doi.org/10.1111/j.1461-0248.2005.00851.x

1053 Wright, S. J., Carrasco, C., Calderon, O., \& Paton, S. (1999). The El Niño Southern Oscillation 1054 variable fruit production, and famine in a tropical forest. Ecology, 80(5), 1632-1647.

1055 Xavier, A. C., King, C. W., \& Scanlon, B. R. (2016). Daily gridded meteorological variables in 1056 Brazil (1980). International Journal of Climatology, 36(6), 2644-2659.

1057 https://doi.org/10.1002/joc.4518

1058 Zartman, C. E., Amaral, J. A., Figueiredo, J. N., \& Dambros, C. D. (2015). Drought impacts 1059 survivorship and reproductive strategies of an epiphyllous leafy liverwort in central 1060 Amazonia. Biotropica, 47(2), 172-178.

1061 Zeng, N., Yoon, J. H., Marengo, J. A., Subramaniam, A., Nobre, C. A., Mariotti, A., \& Neelin, J. D. 1062 (2008). Causes and impacts of the 2005 Amazon drought. Environmental Research Letters, 1063 3(1), 1-9. https://doi.org/10.1088/1748-9326/3/1/014002 